\title{
Laboratory studies of the chemical composition and cloud condensation nuclei (CCN) activity of secondary organic aerosol (SOA) and oxidized primary organic aerosol (OPOA)
}

\author{
A. T. Lambe ${ }^{1,2}$, T. B. Onasch ${ }^{1,2}$, P. Massoli ${ }^{2}$, D. R. Croasdale ${ }^{1}$, J. P. Wright ${ }^{1}$, A. T. Ahern ${ }^{1,2}$, L. R. Williams ${ }^{2}$, \\ D. R. Worsnop ${ }^{2}$, W. H. Brune ${ }^{3}$, and P. Davidovits ${ }^{1}$ \\ ${ }^{1}$ Chemistry Department, Boston College, Chestnut Hill, MA, USA \\ ${ }^{2}$ Aerodyne Research Inc., Billerica, MA, USA \\ ${ }^{3}$ Department of Meteorology and Atmospheric Sciences, The Pennsylvania State University, State College, PA, USA
}

Received: 25 April 2011 - Published in Atmos. Chem. Phys. Discuss.: 4 May 2011

Revised: 24 August 2011 - Accepted: 26 August 2011 - Published: 1 September 2011

\begin{abstract}
Secondary organic aerosol (SOA) and oxidized primary organic aerosol (OPOA) were produced in laboratory experiments from the oxidation of fourteen precursors representing atmospherically relevant biogenic and anthropogenic sources. The SOA and OPOA particles were generated via controlled exposure of precursors to $\mathrm{OH}$ radicals and/or $\mathrm{O}_{3}$ in a Potential Aerosol Mass (PAM) flow reactor over timescales equivalent to 1-20 days of atmospheric aging. Aerosol mass spectra of SOA and OPOA were measured with an Aerodyne aerosol mass spectrometer (AMS). The fraction of AMS signal at $m / z=43$ and $m / z=44\left(f_{43}\right.$, $\left.f_{44}\right)$, the hydrogen-to-carbon $(\mathrm{H} / \mathrm{C})$ ratio, and the oxygen-tocarbon $(\mathrm{O} / \mathrm{C})$ ratio of the SOA and OPOA were obtained, which are commonly used to characterize the level of oxidation of oxygenated organic aerosol (OOA). The results show that PAM-generated SOA and OPOA can reproduce and extend the observed $f_{44}-f_{43}$ composition beyond that of ambient OOA as measured by an AMS. Van Krevelen diagrams showing $\mathrm{H} / \mathrm{C}$ ratio as a function of $\mathrm{O} / \mathrm{C}$ ratio suggest an oxidation mechanism involving formation of carboxylic acids concurrent with fragmentation of carbon-carbon bonds. Cloud condensation nuclei (CCN) activity of PAM-generated SOA and OPOA was measured as a function of $\mathrm{OH}$ exposure and characterized as a function of $\mathrm{O} / \mathrm{C}$ ratio. $\mathrm{CCN}$ activity of the SOA and OPOA, which was characterized in the form of the hygroscopicity parameter $\kappa_{\text {org }}$, ranged from $8.4 \times 10^{-4}$ to 0.28 over measured $\mathrm{O} / \mathrm{C}$ ratios ranging from 0.05 to 1.42 .
\end{abstract}

Correspondence to: A. T. Lambe (andrew.lambe@bc.edu)
This range of $\kappa_{\text {org }}$ and $\mathrm{O} / \mathrm{C}$ ratio is significantly wider than has been previously obtained. To first order, the $\kappa_{\text {org }}$-to-O/C relationship is well represented by a linear function of the form $\kappa_{\mathrm{org}}=(0.18 \pm 0.04) \times \mathrm{O} / \mathrm{C}+0.03$, suggesting that a simple, semi-empirical parameterization of OOA hygroscopicity and oxidation level can be defined for use in chemistry and climate models.

\section{Introduction}

The physical and chemical properties of organic aerosols (OA) are highly complex. Due to atmospheric processes such as dilution, mixing and oxidative aging that result in formation of oxygenated OA (OOA; Zhang et al., 2005), OA properties are highly dynamic, making their characterization challenging. The task is further complicated by limitations in common measurement techniques (often incomplete and indirect) that are typically used to characterize OA in situ. Current knowledge is summarized in several articles (Fuzzi et al., 2006; Kroll and Seinfeld, 2008; Hallquist et al., 2009; Jimenez et al., 2009).

The characterization of OOA in climate models requires simplifying parameterizations of aerosol chemical and physical properties (Kanakidou et al., 2005). Laboratory and field measurements have shown that meaningful simplified representations of OOA chemical composition are possible (Murphy et al., 2006; DeCarlo et al., 2006; Pratt et al., 2009; Hawkins et al., 2010; Mazzoleni et al., 2010). Source apportionment of OA using Aerodyne aerosol mass spectrometer (AMS) measurements has been widely used over the

Published by Copernicus Publications on behalf of the European Geosciences Union. 
last several years (e.g. Zhang et al., 2005; Lanz et al., 2007; Hildebrandt et al., 2010). Ng et al. (2010) demonstrated that the measured fraction of AMS organic signals at $\mathrm{m} / \mathrm{z}=43$ $\left(f_{43}\right)$ and $m / z=44\left(f_{44}\right)$ provide a reasonable representation of the OOA oxidation level. In general, the AMS $f_{44}$ increases and the AMS $f_{43}$ decreases with oxidation level of the OOA. Based on higher mass resolution AMS measurements (Aiken et al., 2010; DeCarlo et al., 2010; He et al., 2010), the increase in $f_{44}$ is interpreted to be due to formation of $\mathrm{CO}_{2}^{+}$ions, while the decrease in $f_{43}$ is due to oxidation of $\mathrm{C}_{3} \mathrm{H}_{7}^{+}$and/or $\mathrm{C}_{2} \mathrm{H}_{3} \mathrm{O}^{+}$ions. High-resolution AMS measurements have made it possible to obtain more detailed information about OOA mass spectra, leading to other simplifying representations. One such representation, which is not limited to AMS measurements, focuses on the ensemble oxygen-to-carbon $(\mathrm{O} / \mathrm{C})$ and hydrogen-to-carbon $(\mathrm{H} / \mathrm{C})$ ratios of organic aerosols (Aiken et al., 2008; Wozniak et al., 2008; Heald et al., 2010; Mazzoleni et al., 2010; Kroll et al., 2011).

Inadequate representation of OOA CCN activity is a potentially large source of uncertainty in climate models (Ghan and Schwartz, 2007; Liu and Wang, 2010). Field experiments have measured OOA with higher CCN activity in air masses that are distant from sources and characterized by increased atmospheric processing (Chang et al., 2010; Wang et al., 2010). Laboratory experiments have also shown that the hygroscopicity of SOA and OPOA increases as a function of oxidant exposure (Huff Hartz et al., 2005; Varutbangkul et al., 2006; Petters et al., 2006; Shilling et al., 2007; AsaAwuku et al., 2009; George et al., 2009, 2010; Poulain et al., 2010; Engelhart et al., 2011). Therefore, an important objective of ongoing studies is determining simple correlations of relevant chemical and physical properties of OOA using readily measured parameters (Jimenez et al., 2009). A recent study by Massoli et al. (2010) characterized the CCN activity of SOA generated from three precursors over oxidation exposures equivalent to $0.5-10$ days of atmospheric aging. Massoli et al. found that $\mathrm{CCN}$ activity was positively correlated with the SOA O/C ratio $(\mathrm{O} / \mathrm{C}=0.38-0.98)$ and had hygroscopic properties similar to ambient OOA. While these studies have provided a baseline characterization of SOA and OPOA CCN activity, they span a small subset of atmospherically relevant precursors and oxidation timescales.

In the present work, we generate SOA and OPOA from the oxidation of fourteen precursors using a Potential Aerosol Mass (PAM) flow reactor (Kang et al., 2007; Lambe et al., 2011). In addition to SOA generated from the oxidation of well-known volatile organic compound (VOC) precursors, we characterize the properties of SOA generated from oxidation of intermediate volatility organic compounds (IVOC), which have recently been identified as potentially important sources of SOA (Robinson et al., 2007; Chan et al., 2009; Presto et al., 2009; de Gouw et al., 2011). Mass spectral measurements of PAM-generated SOA and OPOA are obtained with the AMS. The $f_{44}$ and $f_{43}$ measurements are correlated with corresponding $\mathrm{H} / \mathrm{C}$ and $\mathrm{O} / \mathrm{C}$ ratio measurements to relate unit mass resolution AMS measurements to the more universal $\mathrm{H} / \mathrm{C}$ and $\mathrm{O} / \mathrm{C}$ elemental ratios (Ng et al., 2011b). Van Krevelen diagrams are used to provide insight into possible oxidation mechanisms (Van Krevelen, 1950). The CCN activity of the SOA and OPOA is characterized using the hygroscopicity parameter $\kappa$, and a correlation between $\kappa$ and $\mathrm{O} / \mathrm{C}$ ratio is obtained.

\section{Experimental methods}

\subsection{Overview}

The SOA and OPOA precursors were oxidized in a PAM flow reactor, which is a horizontal 151 glass cylindrical chamber $46 \mathrm{~cm}$ long $\times 22 \mathrm{~cm}$ ID. Organic species were transported through the PAM reactor by a carrier gas consisting of $8.5 \mathrm{lpm} \mathrm{N}_{2}$ and $0.5 \mathrm{lpm} \mathrm{O}$. The average species residence time in the PAM reactor was typically $100 \mathrm{~s}$. Four mercury lamps (BHK Inc.) with peak emission intensity at $\lambda=254 \mathrm{~nm}$ were mounted in teflon-coated quartz cylindrical sleeves inside the chamber, and were continually purged with $\mathrm{N}_{2}$. The size distribution and AMS spectra of PAM-generated SOA and OPOA were measured with a combination of a Scanning Mobility Particle Sizer (SMPS, TSI 3080 DMA and 3010 CPC, 5:1 sheath-to-aerosol flow ratio) and an AMS, respectively. The aerosol was size-selected by a DMA (Differential Mobility Analyzer) prior to CCN measurements with a continuous flow CCN counter (CCNC, Droplet Measurement Technologies) operated at $0.5 \mathrm{lpm}$. A simplified schematic diagram of the experimental setup is shown in Fig. 1. Input lines 1 and 2 provided carrier gases $\left(\mathrm{N}_{2}, \mathrm{O}_{2}\right)$ and $\mathrm{OH}$ radical precursors $\left(\mathrm{O}_{3}, \mathrm{H}_{2} \mathrm{O}\right)$. Lines 3 , 4, and 5 supplied SOA and OPOA precursors that are discussed in Sect. 2.3. Prior to each experiment, the PAM reactor was conditioned with $\mathrm{OH}$ radicals until a particle background less than $10 \mathrm{~cm}^{-3}$ was attained.

\subsection{OH radical generation}

$\mathrm{OH}$ radicals were produced via the reaction $\mathrm{O}_{3}+\mathrm{h} v \rightarrow \mathrm{O}_{2}$ $+\mathrm{O}\left({ }^{1} \mathrm{D}\right)$ followed by the reaction $\mathrm{O}\left({ }^{1} \mathrm{D}\right)+\mathrm{H}_{2} \mathrm{O} \rightarrow 2 \mathrm{OH}$. $\mathrm{O}_{3}$ was generated by irradiating $\mathrm{O}_{2}$ with a mercury lamp $(\lambda=185 \mathrm{~nm})$ outside the PAM reactor. The $\mathrm{O}_{3}$ concentration was measured using an $\mathrm{O}_{3}$ monitor (2B Technologies). Oxygen $\left(\mathrm{O}\left({ }^{1} \mathrm{D}\right)\right)$ radicals were produced by UV photolysis of $\mathrm{O}_{3}$ inside the PAM reactor. The radical $\mathrm{O}\left({ }^{1} \mathrm{D}\right)$ then reacted with water vapor (introduced using a heated Nafion membrane humidifier; Perma Pure LLC) to produce $\mathrm{OH}$ radicals inside the PAM reactor. Most experiments were conducted at relative humidities ranging from $30 \%$ to $40 \%$, depending on the temperature in the PAM reactor $\left(22-32^{\circ} \mathrm{C}\right)$ at different UV lamp settings. At a given measured relative humidity, 


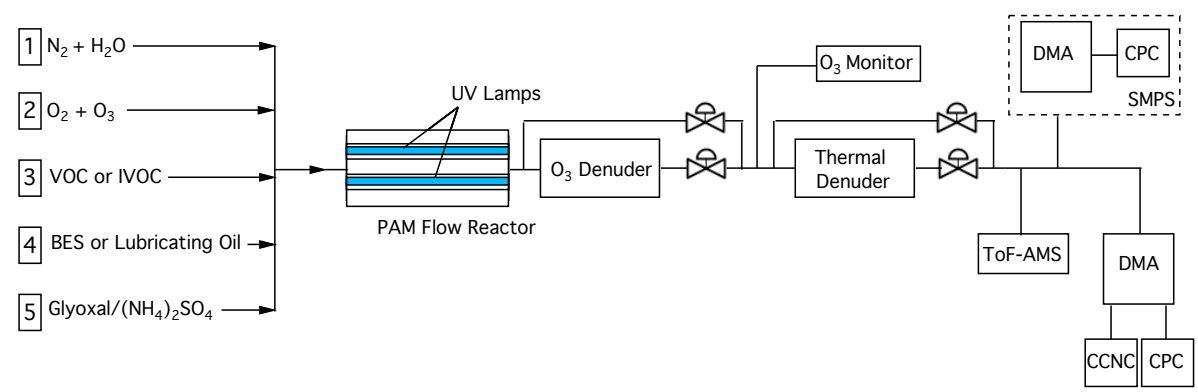

Fig. 1. Simplified schematic of experimental setup. As indicated, input lines 1 and 2 provide carrier gases $\left(\mathrm{N}_{2}, \mathrm{O}_{2}\right)$ and $\mathrm{OH}$ radical precursors $\left(\mathrm{O}_{3}, \mathrm{H}_{2} \mathrm{O}\right)$. Line 3,4 , and 5 provide precursors for SOA and OPOA production as described in Sect. 2.3.

this parameter remained constant to within $\pm 5 \%$. A subset of experiments was performed at higher RH $(52 \%-60 \%)$ and is discussed in more detail in Sect. 2.3.

The $\mathrm{OH}$ exposure, which is the product of the $\mathrm{OH}$ concentration and the average residence time in the PAM reactor, was varied by changing the UV light intensity through stepping the voltage applied to the lamps between 0 and $110 \mathrm{~V}$. The $\mathrm{OH}$ exposure was obtained indirectly by measuring the decay of $\mathrm{SO}_{2}$ due to reaction with $\mathrm{OH}$ in the PAM reactor. $\mathrm{SO}_{2}$ calibration measurements were conducted as a function of UV lamp intensity and $\mathrm{O}_{3}$ concentration (Lambe et al., 2011). Typical $\mathrm{OH}$ exposures ranged from $(1.6 \pm 0.8) \times 10^{11}$ to $(2.5 \pm 0.5) \times 10^{12} \mathrm{molec} \mathrm{cm}^{-3} \mathrm{~s}$. Exposures in this range are equivalent to 1-20 days of atmospheric oxidation assuming an average atmospheric $\mathrm{OH}$ concentration of $1.5 \times 10^{6} \mathrm{molec} \mathrm{cm}^{-3}$ (Mao et al., 2009). Both $\mathrm{O}_{3}$ and $\mathrm{OH}$ can oxidize organic species. However, even with $\mathrm{O}_{3}$ present, $\mathrm{OH}$ was the principal oxidant in all experiments except for selected studies with $\alpha$-pinene and $\beta$-pinene, where experiments with $\mathrm{O}_{3}$ as the oxidizing agent were conducted by turning the lamps off.

$\mathrm{OH}$ concentrations in these experiments (approximately $2 \times 10^{9}$ to $2 \times 10^{10} \mathrm{molec} \mathrm{cm}^{-3}$ ) are higher than ambient $\mathrm{OH}$ concentrations, although the integrated $\mathrm{OH}$ exposures are similar. To first order, a heterogenous oxidation kinetics study by Renbaum and Smith (2011) found that increasing the $\mathrm{OH}$ concentration from $8 \times 10^{8}$ to $2.6 \times 10^{10} \mathrm{molec} \mathrm{cm}^{-3}$ while decreasing the corresponding flow tube residence time from 66 to $2 \mathrm{~s}$ yielded similar results. From their analysis, they suggest that extrapolation of flow tube reactor conditions (high $[\mathrm{OH}]$, short exposure times) to atmospheric conditions (low $[\mathrm{OH}]$, long exposure times) is appropriate.

The most significant experimental artifact arising from the use of high $\mathrm{OH}$ concentrations is probably nonreactive absorption of $\mathrm{O}_{3}$ on the surface of particles (Renbaum and Smith, 2011). $\mathrm{O}_{3}$ absorption may block active sites on the surface of particles that would otherwise be available for heterogenous oxidation by $\mathrm{OH}$ radicals. At $\mathrm{O}_{3}$ levels used in the present work, the results of Renbaum and Smith suggest a $\sim 30 \%$ decrease in the rate of heterogenous oxidation reac- tions as a result of $\mathrm{O}_{3}$ absorption. In addition to $\mathrm{OH}$ and $\mathrm{O}_{3}$ concentrations, other parameters that can potentially differ from atmospheric conditions and induce experimental artifacts are oxidant ratios (e.g. $\mathrm{OH} / \mathrm{HO}_{2}, \mathrm{HO}_{2} / \mathrm{RO}_{2}$ ), precursor and aerosol concentrations, and wall interactions. All laboratory chambers, including smog chambers, are subjected to these artifacts (Matsunaga and Ziemann, 2010; Lambe et al., 2011). One advantage of the PAM reactor is that wall losses are reduced relative to smog chambers.

\subsection{Particle generation}

Figure S1 in the Supplement shows molecular structures of SOA and OPOA precursors used in the present work. SOA was generated via gas-phase oxidation of VOCs and IVOCs, followed by homogenous nucleation. Subsequent heterogenous oxidation of the SOA is possible, but is likely too slow to be of significance relative to much faster oxidation in the gas phase (Lambe et al., 2009). OPOA was generated via heterogenous oxidation of condensed-phase precursors.

The VOC precursors used in this study were $n$-decane $(n$ $\mathrm{C}_{10}$ ), isoprene, $\alpha$-pinene, $\beta$-pinene, toluene, $\mathrm{m}$-xylene, and mesitylene. VOC precursors were prepared in compressed gas cylinders and introduced into the PAM reactor at controlled rates using a mass-flow controller. Depending on the specific study, mixing ratios of the gas-phase precursors entering the PAM reactor ranged from 50 to $330 \mathrm{ppb}$ (see Table $\mathrm{S} 1$ in the Supplement). The IVOC precursors used in this study were $n$-heptadecane $\left(n-\mathrm{C}_{17}\right)$, diesel fuel, longifolene, and naphthalene. With the exception of naphthalene, IVOCs were introduced into the carrier gas flow using a permeation tube placed in a temperature-controlled oven as described by McKinley (2008). Naphthalene vapor was introduced by flowing $\mathrm{N}_{2}$ over solid naphthalene placed in a Teflon tube (Chan et al., 2009). Representative size distributions of SOA generated from $\alpha$-pinene and naphthalene are shown in Fig. S2 of the Supplement. Semivolatile oxidation products may have partitioned less to the condensed phase as a result of UV lamp-induced temperature changes in the PAM reactor. 
Table 1. $f_{44}$ and $f_{43}$ for PAM-generated SOA/OPOA. Column 1 lists SOA/OPOA precursor, and "maxOH" and "minOH" denote measurements at the maximum $\left(\sim 2 \times 10^{12}\right.$ molec $\left.\mathrm{cm}^{-3} \mathrm{~s}\right)$ and minimum $\left(\sim 1 \times 10^{11}\right.$ molec $\left.\mathrm{cm}^{-3} \mathrm{~s}\right) \mathrm{OH}$ exposures, respectively. Typical measurement uncertainty is $5-10 \%$.

\begin{tabular}{lrrrr}
\hline Precursor & $f_{44, \mathrm{maxOH}}$ & $f_{43, \mathrm{maxOH}}$ & $f_{44, \mathrm{minOH}}$ & $f_{43, \mathrm{minOH}}$ \\
\hline$n$ - $\mathrm{C}_{10}$ & 0.27 & 0.043 & 0.038 & 0.11 \\
$n$ - $\mathrm{C}_{17}$ & 0.30 & 0.030 & 0.025 & 0.10 \\
diesel fuel & 0.26 & 0.05 & 0.06 & 0.11 \\
lubricating oil & 0.035 & 0.087 & 0.0038 & 0.10 \\
BES & 0.055 & 0.076 & 0.013 & 0.054 \\
isoprene & 0.12 & 0.12 & 0.077 & 0.16 \\
$\alpha$-pinene & 0.28 & 0.064 & 0.085 & 0.16 \\
$\beta$-pinene & 0.27 & 0.044 & 0.065 & 0.11 \\
longifolene & 0.21 & 0.045 & 0.040 & 0.055 \\
glyoxal & 0.39 & 0.001 & 0.029 & 0.002 \\
toluene & 0.31 & 0.021 & 0.16 & 0.09 \\
m-xylene & 0.30 & 0.048 & 0.095 & 0.17 \\
mesitylene & 0.25 & 0.079 & 0.069 & 0.21 \\
naphthalene & 0.29 & 0.010 & 0.073 & 0.0079 \\
\hline
\end{tabular}

OPOA was generated by heterogenous oxidation of bis(2ethylhexyl) sebacate (BES) and 10W-30 engine lubricating oil particles. BES and lubricating oil particles were generated via homogenous nucleation in a heated flask. Particles were size-selected with a DMA (TSI 3071A) and were transported through an activated charcoal denuder that removed organic gas-phase and volatile condensed-phase species before the particles entered into the PAM reactor. BES and lubricating oil particle diameters were $145 \mathrm{~nm}$ and $200 \mathrm{~nm}$ respectively. The purpose of the denuder was to maximize the role of heterogenous oxidation in experiments with POA precursors (BES and lubricating oil). The influence of the denuder on gas-particle partitioning was minimal for BES because of its low volatility, but was significant for lubricating oil: about $60 \%$ of the lubricating oil was removed from denuding. As a result, the influence of evaporation-oxidationrecondensation cycling of OPOA, which has been observed in previous studies (Miracolo et al., 2010), was minimized in the lubricating oil experiments.

Another set of experiments was conducted with an internally mixed primary aerosol composed of glyoxal and ammonium sulfate. Particles were generated by atomizing an aqueous solution of glyoxal and ammonium sulfate using a constant output atomizer (TSI 3076). To ensure that particles remained well above the crystallization relative humidity of ammonium sulfate, the RH in the PAM reactor was controlled in the range of $52 \%$ to $60 \%$ for these experiments. A separate calibration of the $\mathrm{OH}$ exposure using $\mathrm{SO}_{2}$ was performed at these conditions. While the oxidized glyoxal/sulfate particles are OPOA, we instead refer to this material as SOA to more accurately reflect secondary formation of glyoxal in the atmosphere.
Table 2. Average Van Krevelen slopes $[(\mathrm{H} / \mathrm{C}) /(\mathrm{O} / \mathrm{C})]$ of PAMgenerated SOA/OPOA. Typical slope uncertainty is $10-20 \%$.

\begin{tabular}{ll}
\hline Precursor & Slope \\
\hline$n-\mathrm{C}_{10}$ & -0.80 \\
$n-\mathrm{C}_{17}$ & -0.60 \\
diesel fuel & -0.64 \\
lubricating oil & -1.7 \\
BES & -0.87 \\
isoprene & -0.87 \\
$\alpha$-pinene & -0.48 \\
$\beta$-pinene & -0.57 \\
longifolene & -0.45 \\
glyoxal & -1.2 \\
toluene & -0.48 \\
m-xylene & -0.46 \\
mesitylene & -0.55 \\
naphthalene & -0.05 \\
\hline
\end{tabular}

\subsection{Particle monitoring and analysis}

Particles exiting the PAM reactor passed through an annular denuder filled with Carulite 200 catalyst (Carus Corp.) that selectively removed ozone with a denuding efficiency $>80 \%$. Particle number concentrations and size distributions were measured with an SMPS.

Mass spectra of the aerosol were measured with an Aerodyne time-of-flight aerosol mass spectrometer (ToF-AMS) (Drewnick et al., 2005; DeCarlo et al., 2006). Elemental analysis yielding $\mathrm{O} / \mathrm{C}$ and $\mathrm{H} / \mathrm{C}$ ratios was performed on high-resolution ToF-AMS (HR-ToF-AMS) measurements. In some experiments this instrument was not available and measurements were performed with a lower resolution compact ToF-AMS (c-ToF-AMS). Figures 2, 4, 5, 7, S2, S3, and Table 1 include data collected from both c-ToF-AMS and HR-ToF-AMS measurements. When using c-ToF-AMS measurements presented in Fig. 7, O/C ratios were obtained from $f_{44}$ measurements that were converted to $\mathrm{O} / \mathrm{C}$ ratios using specific HR-ToF-AMS $f_{44}$-to-O/C calibration factors for each system. This is an adaptation of the technique described by Aiken et al. (2008), and is discussed in more detail in Sect. 3.2.

The CCN activity of particles was measured with a continuous flow $\mathrm{CCN}$ counter (CCNC) using a previously described technique (Roberts and Nenes, 2005; Lance et al., 2006). Briefly, the aerosol was size-selected using a TSI 3080 DMA prior to $\mathrm{CCN}$ number concentration measurements with the CCNC and total particle number concentration measurements with a CPC (TSI 3022A). CCN activation curves were generated by holding the particle size constant while systematically varying the CCNC column temperature gradient to obtain controlled water vapor supersaturation between $0.1-1.5 \%$ or until $100 \%$ activation was reached, whichever occurred first. The water vapor supersaturation 
was calibrated using size-selected ammonium sulfate particles with dry diameters ranging from 25 to $85 \mathrm{~nm}$. At each size, the critical supersaturation was calculated from standard Köhler theory, assuming the surface tension of pure water and complete dissociation of ammonium sulfate in solution. If dissociation of ammonium sulfate was incomplete, the calibrated supersaturation values are biased low relative to the true supersaturation values. The $\mathrm{CCN}$ hygroscopicity parameter, $\kappa$, was calculated using Eq. (1) (Petters and Kreidenweis, 2007), which was solved using a $\kappa$-lookup table (http://www4.ncsu.edu/ mdpetter/code.html):

$S(D)=\frac{D^{3}-D_{d}^{3}}{D^{3}-D_{d}^{3}(1-\kappa)} \exp \left(\frac{4 \sigma_{\mathrm{w}} M_{\mathrm{w}}}{R T \rho_{\mathrm{w}}}\right)$

Here $S$ is the saturation ratio over a droplet, $D$ is the cloud droplet diameter, $D_{\mathrm{d}}$ is the dry diameter of the size-selected particles, $R$ is the universal gas constant, $T$ is the sample temperature, and $M_{\mathrm{w}}, \rho_{\mathrm{w}}$, and $\sigma_{\mathrm{w}}$ are the molecular weight, density, and surface tension of water $\left(\sigma_{\mathrm{w}}=0.072 \mathrm{~J} \mathrm{~m}^{-2}\right)$. The critical supersaturation $s_{\mathrm{c}}$, which is determined from CCNC measurements, corresponds to the maximum value in the $\kappa$ Köhler curve; note that $s_{\mathrm{c}}=S-1$. Selected dry mobility diameters ranged from 45 to $150 \mathrm{~nm}$ for SOA and from 145 to $200 \mathrm{~nm}$ for OPOA. The corresponding lower limits for $\kappa$-values ranged from $0.061(45 \mathrm{~nm})$ to $6 \times 10^{-4}(200 \mathrm{~nm})$. Lower limits for all $\kappa$-values are shown in Figs. S3 and S4 of the Supplement, along with upper limits for $\kappa$-values of unoxidized POA $\left(6 \times 10^{-4}\right)$. Each $\kappa$-value represents an average of 1-4 separate activation experiments.

\section{Results and discussion}

\subsection{PAM-generated SOA/OPOA and its comparison with ambient OOA}

As has been stated, the measured fraction of AMS organic signals at $m / z=43\left(f_{43}\right)$ and $=44\left(f_{44}\right)$ provide a reasonable representation of the OOA oxidation level. The $f_{43}$ component provides a measure of less-oxidized, semivolatile OOA (SV-OOA) while the $f_{44}$ component represents more highly oxidized, low-volatility OOA (LV-OOA) (Huffman et al., 2009; Jimenez et al., 2009). Results of a thermal denuder experiment, which is described in more detail in the Supplement, are in qualitative accord with this interpretation of the $f_{43}$ and $f_{44}$ components. Briefly, PAM-generated naphthalene and $\alpha$-pinene SOA were produced at several $\mathrm{OH}$ exposures in the PAM reactor and then passed through an Aerodyne thermal denuder (Huffman et al., 2008) set to controlled temperatures ranging from 30 to $250{ }^{\circ} \mathrm{C}$. In each case, the $f_{44}$-to- $f_{43}$ ratio increased after heating, as shown in Fig. S5 of the Supplement.

Figure 2 shows $f_{44}$ versus $f_{43}$ for SOA and OPOA generated from individual precursors in the PAM reactor. Data shown in this figure were collected with both the c-ToF-AMS
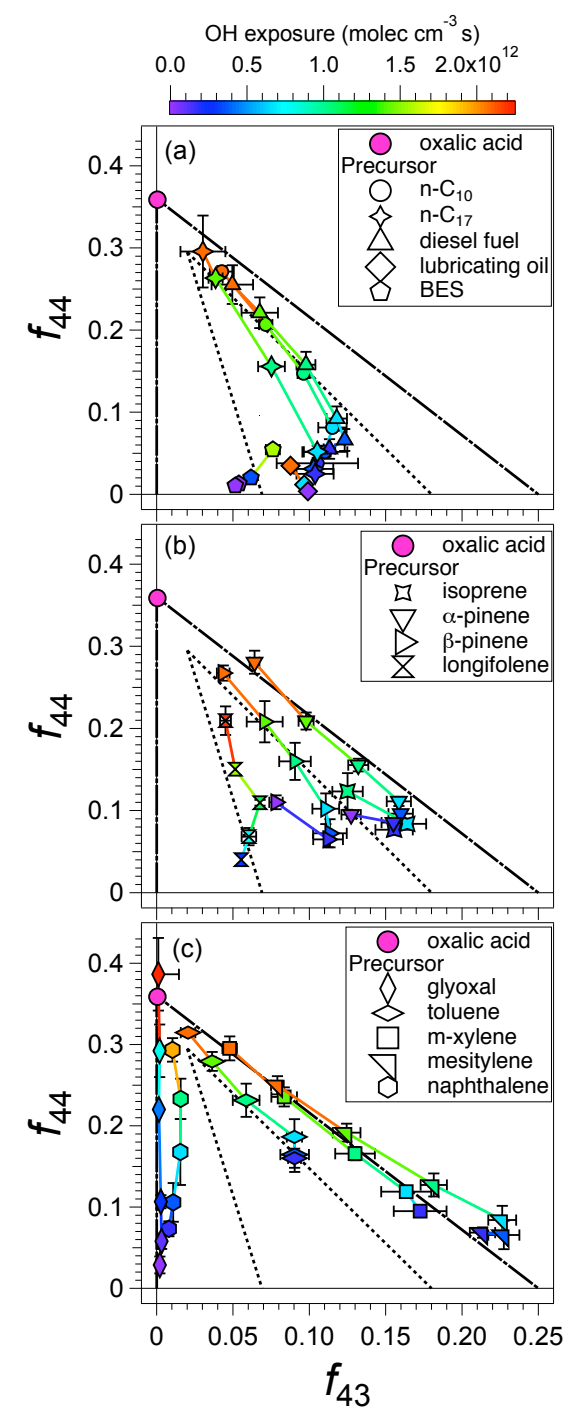

Fig. 2. $f_{44}$ shown as a function of $f_{43}$ for SOA and OPOA generated in the PAM reactor from oxidation of (a) alkanes and BES, (b) biogenic terpenoids, and (c) aromatics and glyoxal. Symbols are colored by $\mathrm{OH}$ exposure; error bars represent $\pm 1 \sigma$ in measurements. Measured $f_{43}$ and $f_{44}$ of oxalic acid shown for reference. Dashed lines indicate range of ambient $f_{44}$ and $f_{43}$ measurements (Ng et al., 2010), while dashed-and-dotted lines indicate range of laboratory measurements. For details see text.

and HR-ToF-AMS. To simplify presentation, the data are displayed in three panels. Figure 2a shows SOA generated from gas-phase alkanes, and OPOA generated from BES and lubricating oil particles. Figure $2 b$ shows SOA generated from biogenic terpenoid precursors, and Fig. 2c shows SOA produced from aromatic compounds and from glyoxal, a known photooxidation product of aromatic compounds (Volkamer et al., 2001; Nishino et al., 2009, 2010). In each figure, SOA/OPOA precursors are designated by symbols shown in the figure inset. The color of the symbols indicates the level 
of $\mathrm{OH}$ exposure in the PAM reactor. Dashed lines indicate the range of $f_{44}$ and $f_{43}$ observed in ambient SV-OOA and LV-OOA factors ( $\mathrm{Ng}$ et al., 2010). In each figure, for comparison, we show $f_{44}$ and $f_{43}$ for an atomized oxalic acid solution ( 0.36 and 0.00048 respectively) measured in the present work. Oxalic acid is a known oxidation product of aqueous glyoxal (Ervens et al., 2004; Carlton et al., 2007), is often the most abundant dicarboxylic acid in ambient OOA (Sorooshian et al., 2006; Takegawa et al., 2007), and represents the highest oxidation state of atmospheric organics present in aerosols (Kroll et al., 2011).

The following features are noted in Fig. 2. (1) For all types of PAM-generated SOA, increasing the $\mathrm{OH}$ exposure increases $f_{44}$ and decreases $f_{43}$. However, as will be discussed, $f_{43}$ first increases and then decreases with $\mathrm{OH}$ exposure in most cases. (2) For the SOA/OPOA displayed in Fig. $2 \mathrm{a}$ and $2 \mathrm{~b}$, the measured $f_{44}$ and $f_{43}$ signals span the range observed in ambient SV-OOA and LV-OOA as indicated by the dashed lines. For SOA/OPOA generated from precursors shown in Fig. 2c (and for some precursors shown in Fig. $2 b), f_{44}$ and $f_{43}$ extend significantly outside the ambient range as delineated by the dashed-and-dotted boundary lines. (3) With increased $\mathrm{OH}$ exposure, $f_{44}$ and $f_{43}$ for all types of PAM-generated SOA/OPOA converge towards the $f_{44}$ and $f_{43}$ of oxalic acid. Table 1 , columns 2 and 3 show $f_{44}$ and the corresponding $f_{43}$ measured at the highest $\mathrm{OH}$ exposure $\left(\sim 2 \times 10^{12}\right.$ molec $\left.^{-3} \mathrm{~s}\right)$ for each type of PAMgenerated SOA/OPOA. Likewise, columns 4 and 5 show $f_{44}$ with the corresponding $f_{43}$ obtained at the lowest $\mathrm{OH}$ exposure $\left(\sim 10^{11}\right.$ molec $\left.\mathrm{cm}^{-3} \mathrm{~s}\right)$. The highest measured $f_{44}$ and corresponding $f_{43}$ for SOA generated from glyoxal are $f_{44}=$ $0.39 \pm 0.05$ and $f_{43}=0.001 \pm 0.01$. These values are similar to those measured in our experiment with oxalic acid $\left(f_{44}=\right.$ $0.36, f_{43}=0.0048$ ). Lee et al. (2011) measured $f_{43}$ and $f_{44}$ for oxalic acid and for organics generated from the oxidation of aqueous glyoxal. In their manuscript they presented results graphically without stating numerical values. From their graphical representation, we estimate $f_{44} \approx 0.3$ and $f_{43}$ $\approx 0$ for both oxalic acid and oxidized aqueous glyoxal.

Figure 2 and Table 1, column 5 indicate that the $f_{43}$ of PAM-generated SOA/OPOA at low $\mathrm{OH}$ exposures varies widely over the range of precursors. This reflects the wide range of precursor structures. As shown in Figs. S6-S8 of the Supplement, the wide range of precursor structures is captured by the complexity of AMS spectra for several types of SOA generated at low $\mathrm{OH}$ exposures. The $f_{43}$ spread is particularly wide for SOA generated from aromatic precursors (Fig. 2c). For this class of compounds, $f_{43}$ is low for SOA generated from non-methylated aromatics (naphthalene) and it increases with precursors of increased methylation, reaching a maximum with mesitylene. The range of measured $f_{43}$, along with the overall complexity of the AMS spectra (Figs. S6-S8), decreases with increasing OH exposure. This is presumably because oxidation converts the lesser-oxidized compounds contributing to $f_{43}$ to products that contribute to $f_{44}$. The region defined by the dashed-and-dotted lines shown in Fig. 2 was constructed to bound the extremes of the $f_{43}$ and $f_{44}$ measurements obtained in the laboratory, with oxalic acid as an oxidation endpoint. As is evident, measurements for SOA generated from glyoxal and mesitylene fall close to the dashed-and-dotted boundary lines.

Several SOA precursors examined in the present work have been characterized in smog chamber studies (Ng et al., 2010; Chhabra et al., 2010, 2011). For a specific precursor, the $f_{44}$ and $f_{43}$ of SOA generated in smog chambers and in the PAM at low $\mathrm{OH}$ exposures are generally similar. Because higher $\mathrm{OH}$ exposures are possible in the PAM reactor than in smog chambers, the range of attained $f_{44}$ increases significantly. One exception is SOA generated from isoprene, which may have fragmented into more volatile products at higher $\mathrm{OH}$ exposures in the PAM reactor (Kroll et al., 2006). This might have prevented the formation of SOA with $f_{44}>0.12$. Further, we note that our experiments were done in the presence of water vapor, which is not always the case for smog chamber studies. Relative humidity can influence the composition and distribution of oxidation products, as has been observed in some studies (e.g. Nguyen et al., 2011; Zhou et al., 2011).

For PAM-generated SOA obtained from the oxidation of nine of the fourteen precursors studied, $f_{43}$ first increases and then decreases with $\mathrm{OH}$ exposure. This change is emphasized in a separate $f_{44}-f_{43}$ graph (Fig. S9 of the Supplement), where data from Fig. 2 are shown to highlight the $f_{44-}$ $f_{43}$ trend for SOA generated from these precursors. Highresolution AMS measurements, which facilitate deconvolution of the total $f_{43}$ signal into separate fractions of organic signal consisting of $\mathrm{C}_{3} \mathrm{H}_{7}^{+}\left(f_{\mathrm{C}_{3} \mathrm{H}_{7}^{+}}\right)$and $\mathrm{C}_{2} \mathrm{H}_{3} \mathrm{O}^{+}\left(f_{\mathrm{C}_{2} \mathrm{H}_{3} \mathrm{O}^{+}}\right)$ ion fragments, revealed that the $f_{43}$ curvature arises from the increase and subsequent decrease in $f_{\mathrm{C}_{2} \mathrm{H}_{3} \mathrm{O}^{+}}$with oxidation. This curvature in $f_{43}$ was observed for SOA generated from gas-phase alkanes, biogenic terpenoids, mesitylene, and naphthalene. Curvature in $f_{44}-f_{43}$ space suggests a progression from earlier-generation oxidation products containing carbonyl functional groups (higher $f_{\mathrm{C}_{2} \mathrm{H}_{3} \mathrm{O}^{+}}$) towards later-generation oxidation products containing acidic functional groups (higher $f_{44}$, lower $f_{\mathrm{C}_{2} \mathrm{H}_{3} \mathrm{O}^{+}}$). These trends will be discussed further in Sect. 3.2. The $f_{43}$ curvature observed in the present work has also been observed in other studies (Kroll et al., 2009; Ng et al., 2010; Chhabra et al., 2011; Lee et al., 2011). However, SOA/OPOA produced from glyoxal, lubricating oil, BES, toluene, and $\mathrm{m}$-xylene did not exhibit the clear $f_{43}$ curvature as observed in Fig. S9. For each of these systems, there are plausible explanations for the absence of observable $f_{43}$ curvature. However, we cannot support these explanations without introducing significant speculation to the discussion.

For SOA generated from the oxidation of gas-phase alkanes and longifolene, both $\mathrm{C}_{3} \mathrm{H}_{7}^{+}$and $\mathrm{C}_{2} \mathrm{H}_{3} \mathrm{O}^{+}$ions contribute appreciable $(>10 \%)$ fractions of the total $\mathrm{m} / \mathrm{z}=43$ signal at 


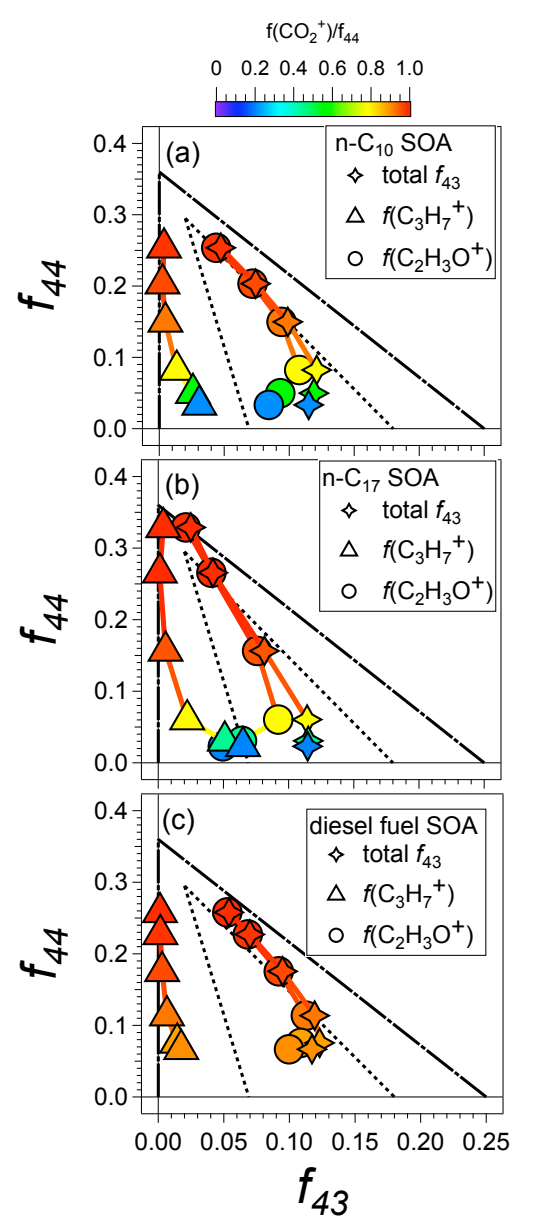

Fig. 3. $f_{44}$ shown as a function of $f_{\mathrm{C}_{3} \mathrm{H}_{7}^{+}}$(blue), $f_{\mathrm{C}_{2} \mathrm{H}_{3} \mathrm{O}^{+}}$(yellow), and total $f_{43}$ (red) for SOA generated in the PAM reactor from the oxidation of (a) $n-\mathrm{C}_{10}$, (b) $n-\mathrm{C}_{17}$, and (c) diesel fuel. Dashed lines indicate range of ambient $f_{44}$ and $f_{43}$ measurements, while dashed-and-dotted lines indicate range of laboratory PAM reactor measurements.

low $\mathrm{OH}$ exposures. In these systems, $f_{\mathrm{C}_{3} \mathrm{H}_{7}^{+}}$increases in the following sequence: longifolene $<$ diesel fuel $<n-\mathrm{C}_{10}<n$ $\mathrm{C}_{17}$. This trend suggests a correlation between carbon chain length of the precursor and $f_{\mathrm{C}_{3} \mathrm{H}_{7}^{+}}$of the SOA. If $\mathrm{C}_{2} \mathrm{H}_{3} \mathrm{O}^{+}$ contributions to $f_{43}$ are isolated in these systems, the extent of $f_{43}$ curvature increases, as shown in Fig. 3 for SOA generated in the PAM reactor from $n-\mathrm{C}_{10}, n-\mathrm{C}_{17}$, and diesel fuel. In addition, for SOA generated from $n-\mathrm{C}_{10}, n-\mathrm{C}_{17}$, and diesel fuel, both $\mathrm{CO}_{2}^{+}$and $\mathrm{C}_{2} \mathrm{H}_{4} \mathrm{O}^{+}$ions contribute appreciable fractions of the $\mathrm{m} / \mathrm{z}=44$ signal at low $\mathrm{OH}$ exposures, as indicated by the Fig. 3 colorbar. To our knowledge, in addition to SOA generated from isoprene at low $\mathrm{OH}$ exposures in this work and in previous studies ( $\mathrm{Ng}$ et al., 2010), these measurements represent the only measurements of laboratory SOA containing significant $\mathrm{C}_{2} \mathrm{H}_{4} \mathrm{O}^{+}$contributions to $\mathrm{m} / \mathrm{z}=44$.

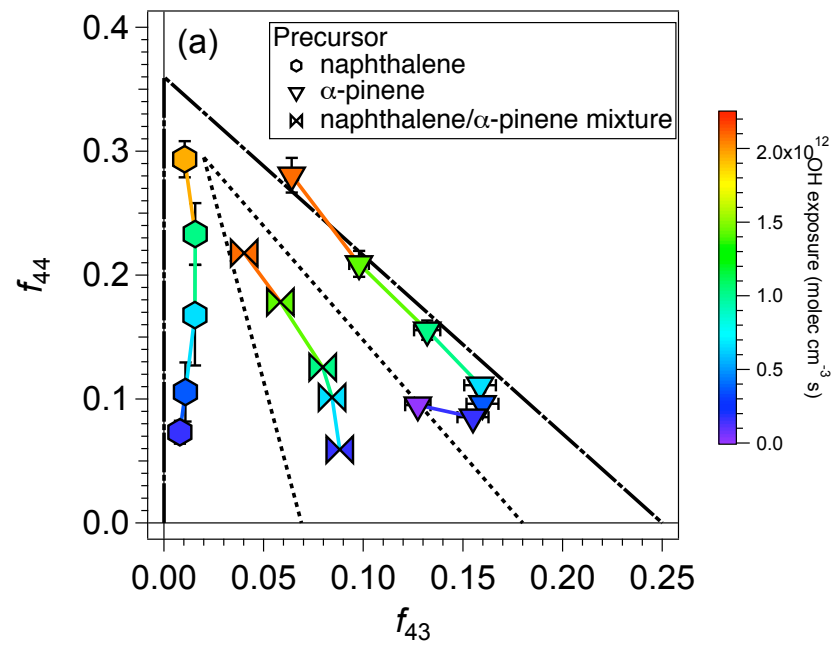

Fig. 4. $f_{44}$ shown as a function of $f_{43}$ for SOA generated in the PAM reactor from a mixture of naphthalene and $\alpha$-pinene. $f_{43}$ and $f_{44}$ data for SOA generated seperately from naphthalene and $\alpha$-pinene are replotted from Fig. 2. Error bars represent $\pm 1 \sigma$ in measurements. Dashed lines indicate range of ambient $f_{44}$ and $f_{43}$ measurements, while dashed-and-dotted lines indicate range of laboratory PAM reactor measurements.

Ambient OOA represents a complex mixture of organics contributed from many precursors. To explore the mass spectral characteristics of SOA generated from mixed precursors, we generated SOA from a mixture of $\sim 50 \%$ naphthalene and $\sim 50 \% \alpha$-pinene at several $\mathrm{OH}$ exposures. The $f_{44}$ and $f_{43}$ for this mixture are shown in Fig. 4 , together with the $f_{44}$ and $f_{43}$ data (from Fig. 2) of SOA generated separately from naphthalene and $\alpha$-pinene. Data shown in this figure were collected with the c-ToF-AMS. The figure shows that mixing two SOA precursors - one generating low- $f_{43}$ SOA and the other generating high- $f_{43} \mathrm{SOA}$ - produces SOA with $f_{43}$ approximately averaged between the two components. Specifically, the $f_{43}$ of the naphthalene/ $\alpha$-pinene SOA mixture ranged from 0.04 to 0.09 , which is between the $f_{43}$ of naphthalene SOA and $\alpha$-pinene SOA at each $\mathrm{OH}$ exposure; a similar result was obtained by Lee et al. (2011) from the aqueous $\mathrm{OH}$ oxidation of a mixture of glyoxal and pinonic acid. In ensemble measurements of laboratory and ambient SOA mixtures, the extreme $f_{43}$ values may be minimized due to averaging. Such a tendency is perhaps evidenced in Fig. 4 and also in Fig. 2, where the ambient OOA measurements fall within a smaller triangle than the laboratory measurements. However, $f_{44}$ of the mixture was always lower than $f_{44}$ of naphthalene SOA and $\alpha$-pinene SOA at a specific $\mathrm{OH}$ exposure. This result suggests that a more quantitative understanding of the mixed SOA composition would require knowledge of the yield and volatility of SOA generated from each precursor, which is beyond the scope of this work.

Positive Matrix Factorization (PMF) is a receptor modeling technique used to extract source factors from temporal 


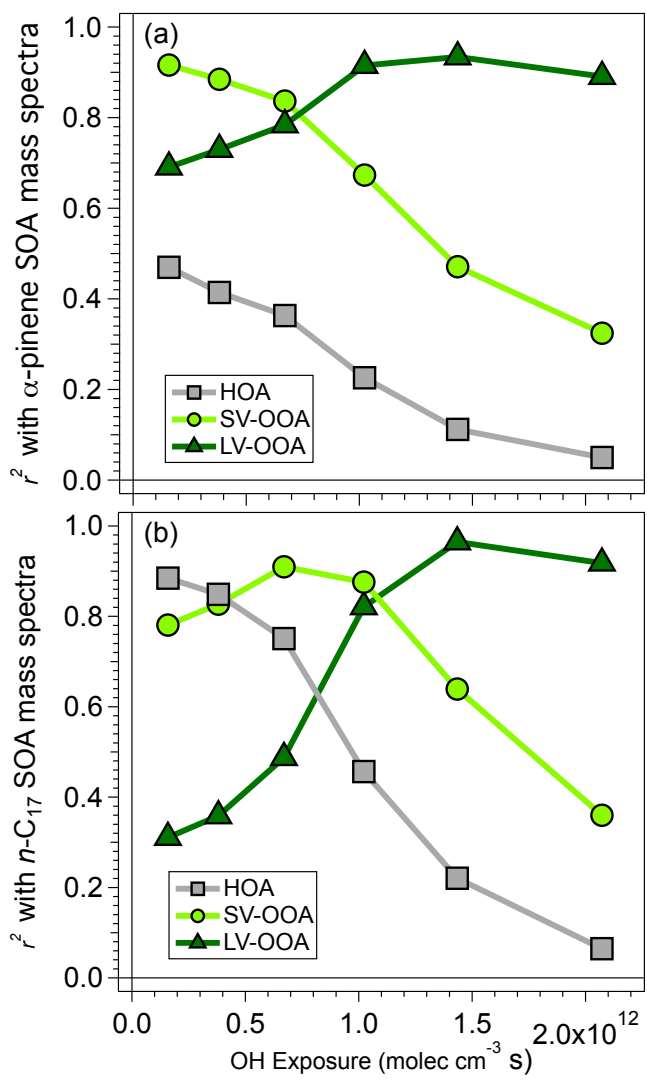

Fig. 5. Linear correlation coefficient $\left(r^{2}\right)$ between mass spectra of PAM-generated (a) $\alpha$-pinene SOA and (b) $n$ - $\mathrm{C}_{17}$ SOA and ambient hydrocarbon-like organic aerosol (HOA), ambient semivolatile OOA (SV-OOA), and ambient low-volatily OOA (LV-OOA) factors (Ng et al., 2011a) as a function of $\mathrm{OH}$ exposure in the PAM reactor.

profiles in field measurements (Paatero and Tapper, 1994). A more detailed comparison of PAM-generated SOA and ambient OA can be obtained using ambient OA factors derived using PMF. With this technique, one can extract mass spectra associated with distinct OA classes: specifically, hydrocarbon-like organic aerosol (HOA), semivolatile OOA (SV-OOA) and low volatility OOA (LV-OOA) (Ulbrich et al., 2009). As was done by Jimenez et al. (2009) and Morgan et al. (2010), we cross-correlated and obtained linear correlation coefficients $\left(r^{2}\right)$ for mass spectra of PAM-generated SOA with mass spectra of composite HOA, SV-OOA, and LV-OOA PMF factors derived from multiple field datasets (Ng et al., 2011a; Ulbrich et al., 2011). Results are shown in Fig. 5a and b for SOA generated in the PAM reactor from $\alpha$-pinene and $n$ - $\mathrm{C}_{17}$ respectively. Data shown in this figure were collected with both the c-ToF-AMS and HR-ToF-AMS. SOA generated from $\alpha$-pinene was well correlated with SVOOA at low $\mathrm{OH}$ exposures $\left(r^{2}=0.88-0.92\right)$ and LV-OOA at high $\mathrm{OH}$ exposures $\left(r^{2}=0.89-0.93\right)$. Similar trends were observed for SOA generated from other precursors. As ex- pected, most types of PAM-generated SOA were poorly correlated with HOA, except for SOA generated from alkanes at low $\mathrm{OH}$ exposures (e.g. $n-\mathrm{C}_{17}$ as shown in Fig. 5 b). These results are consistent with these three PMF factors representing aerosols with increasing residence times in the atmosphere.

\section{2 $\mathrm{H} / \mathrm{C}$ and $\mathrm{O} / \mathrm{C}$ ratios of PAM-generated SOA and OPOA}

An alternate representation of OOA composition uses the Van Krevelen diagram to show changes in the hydrogen-tocarbon $(\mathrm{H} / \mathrm{C})$ and oxygen-to-carbon $(\mathrm{O} / \mathrm{C})$ ratios as a function of oxidative aging. Because $\mathrm{O} / \mathrm{C}$ correlates with $f_{44}$ and $\mathrm{H} / \mathrm{C}$ correlates with $f_{43}$, (Ng et al., 2011b), the diagram is analogous to the $f_{44}-f_{43}$ representation described earlier. Figures S10a and S10b in the Supplement show O/C ratio as a function of $f_{44}$ and $\mathrm{H} / \mathrm{C}$ ratio as a function of $f_{43}$ for PAMgenerated SOA/OPOA. These figures extend the datasets published by Aiken et al. (2008), Chhabra et al. (2010), and $\mathrm{Ng}$ et al. (2011b). Figure S10a shows that with the exception of SOA generated from glyoxal, the $\mathrm{O} / \mathrm{C}-f_{44}$ relationship is linear for all systems studied and well described by the dashed line in the figure $\left(\mathrm{O} / \mathrm{C}=3.82 \times f_{44}+0.0794\right)$, which is the best fit to multiple laboratory and field datasets (Aiken et al., 2008). The deviation observed for glyoxal, which was first reported by Chhabra et al. (2010), is due to the high initial oxygen content of glyoxal $(\mathrm{O} / \mathrm{C} \approx 1)$ despite low $f_{44}$.

Figure S10b shows that, in general, the relationship between $\mathrm{H} / \mathrm{C}$ and $f_{43}$ is monotonically increasing but nonlinear. The black dashed line in the figure $\left(\mathrm{H} / \mathrm{C}=1.01+6.07 \times f_{43}\right.$ $\left.-16.01 \times f_{43}{ }^{2}\right)$ is a quadratic fit to smog chamber and field data (Ng et al., 2011b); grey dashed lines represent $\pm 10 \%$ confidence intervals to the quadratic fit as presented by $\mathrm{Ng}$ et al. (2011). In many cases, PAM-generated SOA/OPOA fall near or within the confidence intervals of the $\mathrm{Ng}$ et al. (2011) parameterization. Several systems lie well outside the confidence intervals or display different $\mathrm{H} / \mathrm{C}-f_{43}$ trends, suggesting that in some cases the relationship between $\mathrm{H} / \mathrm{C}$ ratio and $f_{43}$ is more complicated. For example, SOA generated from glyoxal has significant hydrogen content but does not yield $\mathrm{m} / z=43$ signal; we also note that the $\mathrm{H} / \mathrm{C}$ ratio of unoxidized glyoxal $(\mathrm{H} / \mathrm{C} \approx 1.5)$ is similar to values reported by Chhabra et al. (2010) and may indicate hydration of glyoxal. For OPOA generated from lubricating oil and SOA generated from $n-\mathrm{C}_{10}, n-\mathrm{C}_{17}$, and diesel fuel under low oxidation conditions, a significant fraction of the $m / z=43$ signal consists of $\mathrm{C}_{3} \mathrm{H}_{7}^{+}$ions. This may not have been the case in systems examined by $\mathrm{Ng}$ et al. For OPOA generated from BES, the $\mathrm{H} / \mathrm{C}$ ratio decreases with increasing $f_{43}$, a trend which is the opposite of all other types of PAM-generated SOA and OPOA.

Figure 6 contains Van Krevelen diagrams that show H/C versus $\mathrm{O} / \mathrm{C}$ for SOA/OPOA generated in the PAM reactor from the fourteen precursors shown in Fig. 2 (The reverse of this diagram, i.e. O/C vs. H/C, would provide a closer 


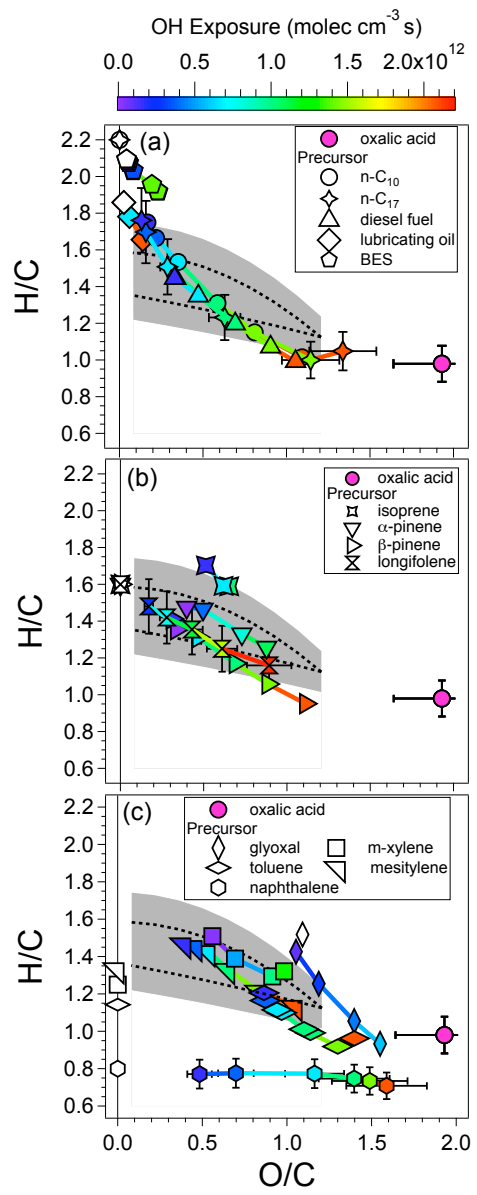

Fig. 6. Van Krevelen diagrams showing $\mathrm{H} / \mathrm{C}$ ratio as a function of $\mathrm{O} / \mathrm{C}$ ratio for SOA and OPOA generated in the PAM reactor from (a) alkanes and BES, (b) biogenic terpenoids, and (c) aromatics and glyoxal. Symbols are colored by $\mathrm{OH}$ exposure, except for open symbols which represent unoxidized precursors (Note: for $n-C_{10}$, $\mathrm{n}-\mathrm{C}_{17}: \mathrm{O} / \mathrm{C}=0$ and $\mathrm{H} / \mathrm{C}=2.2$; for isoprene, $\alpha-/ \beta$-pinene, longifolene: $\mathrm{O} / \mathrm{C}=0$ and $\mathrm{H} / \mathrm{C}=1.6$ ). Measured $\mathrm{H} / \mathrm{C}$ and $\mathrm{O} / \mathrm{C}$ ratios of atomized oxalic acid are shown for reference. Representative error bars indicate $\pm 10 \%$ uncertainty in $\mathrm{H} / \mathrm{C}$ ratios and $\pm 15 \%$ uncertainty in $\mathrm{O} / \mathrm{C}$ ratios. Dashed lines represent range of $\mathrm{H} / \mathrm{C}$ and $\mathrm{O} / \mathrm{C}$ ratios in ambient OOA converted from corresponding $f_{43}$ and $f_{44}$ values; shaded grey region indicates conversion uncertainty as described in $\mathrm{Ng}$ et al. (2011b).

analogy to the $f_{44}-f_{43}$ relationship displayed in Fig. 2. However, we chose the conventional format that has been used to represent products of coal combustion). Data shown in this figure were collected with the HR-ToF-AMS. To simplify presentation, data are displayed in three panels as was done in Fig. 2. Figure 6a SOA generated from gas-phase alkanes and OPOA generated from lubricating oil and BES particles. Figure $6 \mathrm{~b}$ shows SOA generated from biogenic terpenoid precursors, and Fig. 6c shows SOA produced from aromatic compounds and from glyoxal. Open symbols represent atomic $\mathrm{H} / \mathrm{C}$ and $\mathrm{O} / \mathrm{C}$ ratios of the unoxidized precur- sors, except for unoxidized lubricating oil, BES, and glyoxal, where open symbols represent measured $\mathrm{H} / \mathrm{C}$ and $\mathrm{O} / \mathrm{C}$ ratios. Measured $\mathrm{H} / \mathrm{C}$ and $\mathrm{O} / \mathrm{C}$ ratios of oxalic acid are also shown for reference. Dashed lines represent the left- and right-hand sides of the ambient $f_{44}-f_{43}$ triangle converted into Van Krevelen diagram coordinates ( $\mathrm{Ng}$ et al., 2011b); the grey shaded region indicates the associated uncertainty in converting from $f_{44}$ and $f_{43}$ values to $\mathrm{O} / \mathrm{C}$ and $\mathrm{H} / \mathrm{C}$ ratios.

Consistent with observations discussed in connection with Fig. 2, the following features are noted in Fig. 6. (1) As expected, increasing the $\mathrm{OH}$ exposure increases the $\mathrm{O} / \mathrm{C}$ ratio and, in most cases, decreases the H/C ratio. (2) Measured $\mathrm{H} / \mathrm{C}$ and $\mathrm{O} / \mathrm{C}$ ratios of PAM-generated SOA and OPOA span the range observed in ambient OOA as indicated by the dashed lines. As in Figs. 2 and 4, mixing multiple SOA precursors may cause extreme $\mathrm{H} / \mathrm{C}$ ratios to be averaged out towards the center. (3) For most types of PAM-generated SOA/OPOA, the measured $\mathrm{H} / \mathrm{C}$ and $\mathrm{O} / \mathrm{C}$ ratios converge towards the $\mathrm{H} / \mathrm{C}$ and $\mathrm{O} / \mathrm{C}$ ratios of oxalic acid.

The rate at which the $\mathrm{H} / \mathrm{C}$ ratio changes with the $\mathrm{O} / \mathrm{C}$ ratio in Van Krevelen diagrams can provide information about functional groups that may have formed in the process of oxidation. As discussed in Heald et al. (2010), a slope of zero in Van Krevelen space $(\Delta \mathrm{H} / \mathrm{C}=0)$ is consistent with addition of alcohol groups to a carbon backbone. A slope of -2 $(\Delta \mathrm{H} / \mathrm{C}=-2 \times \Delta \mathrm{O} / \mathrm{C}$ ) is due to addition of carbonyl groups, and a slope of $-1(\Delta \mathrm{H} / \mathrm{C}=-\Delta \mathrm{O} / \mathrm{C})$ is consistent with formation of carboxylic acid groups, or alcohol plus carbonyl groups. As discussed by $\mathrm{Ng}$ et al. (2011b), addition of carboxylic acid groups concurrent with $\mathrm{C}-\mathrm{C}$ bond cleavage can yield slopes between -1 and 0 .

Average $(\mathrm{H} / \mathrm{C}) /(\mathrm{O} / \mathrm{C})$ slopes calculated for PAMgenerated SOA and OPOA were obtained from data in Fig. 6 and are shown in Table 2. Consistent with results of Massoli et al. (2010) and Chhabra et al. (2011), most of the measured slopes range from -0.87 to -0.45 , suggesting that oxidative aging in these systems forms primarily carboxylic acid groups (or carbonyl and alcohol groups) and breaks carbon-carbon bonds, leading to fragmentation. $\mathrm{Ng}$ et al. (2011b) found $(\mathrm{H} / \mathrm{C}) /(\mathrm{O} / \mathrm{C})$ slopes $\approx-0.5$ for ambient OOA, which falls in the midrange of our measurements. The SOA generated from isoprene and gas-phase alkanes have steeper average $(\mathrm{H} / \mathrm{C}) /(\mathrm{O} / \mathrm{C})$ slopes $(-0.87$ to -0.60$)$ than ambient OOA, particularly at low $\mathrm{OH}$ exposures in the PAM reactor, where the $\mathrm{H} / \mathrm{C}$ ratio decreased faster than at higher $\mathrm{OH}$ exposures. As shown in Fig. 6a, the $\mathrm{H} / \mathrm{C}$ ratios of SOA generated from alkanes and isoprene at low $\mathrm{OH}$ exposures range from 1.6 to 2.1 , which is on the high end of $\mathrm{H} / \mathrm{C}$ ratios typically measured in ambient OOA.

PAM-generated lubricating oil, naphthalene, and glyoxal SOA/OPOA displayed different trends with oxidation. The $(\mathrm{H} / \mathrm{C}) /(\mathrm{O} / \mathrm{C})$ slope of OPOA generated from lubricating oil was $-1.7 \pm 0.2$. The $\mathrm{H} / \mathrm{C}$ ratio of SOA generated from naphthalene is lower than the range of $\mathrm{H} / \mathrm{C}$ ratios typically measured in ambient OOA. In addition, the $\mathrm{H} / \mathrm{C}$ ratio of SOA 


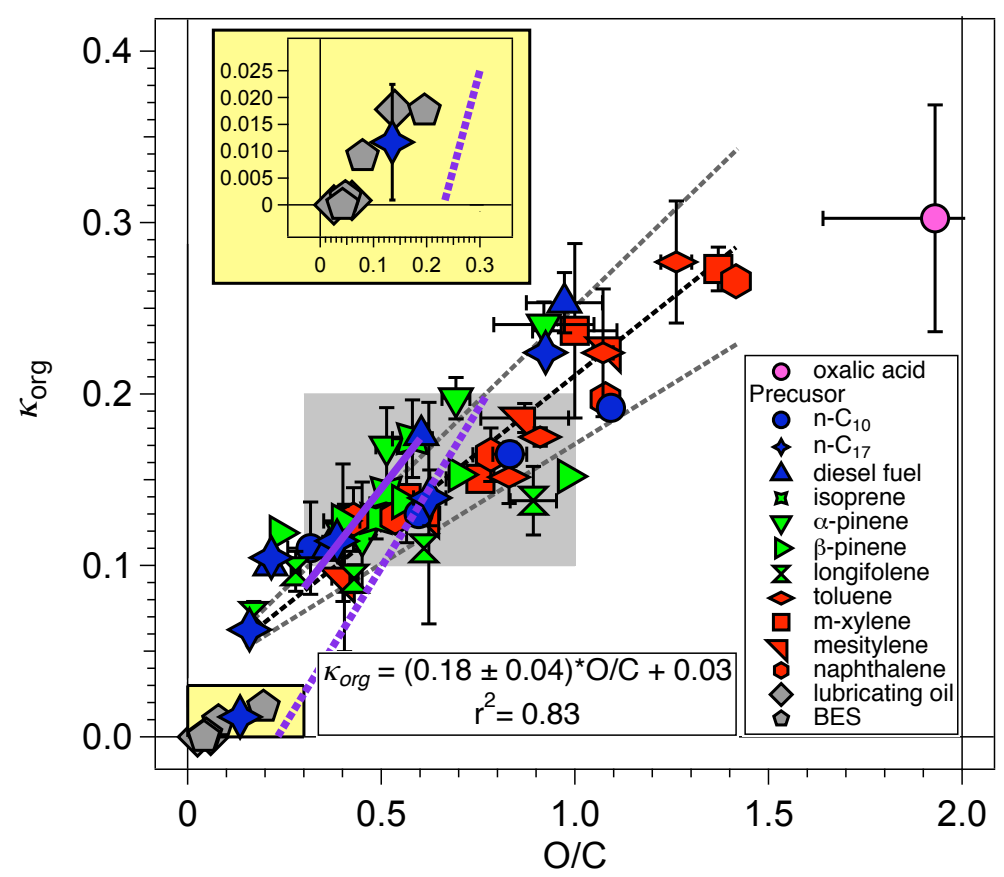

Fig. 7. CCN-derived hygroscopicity parameter $\left(\kappa_{\mathrm{org}}\right)$ shown as a function of O/C ratio for PAM-generated SOA and OPOA. Symbols are colored by precursor class (blue: gas-phase alkanes, green: biogenic terpenoids, red: aromatics, grey: POA), and error bars represent $\pm 1 \sigma$ in measurements. Figure inset shows low $\kappa_{\text {org }}$ measurements of OPOA and $n-\mathrm{C}_{17}$ SOA on an expanded scale. Measured $\kappa_{\text {org }}$ of oxalic acid is shown for reference. Solid black line indicates a linear fit to the data (slope $=0.18$, intercept $=0.03, r^{2}=0.83$ ) with dashed black lines representing $\pm 1 \sigma$ confidence intervals. Purple dashed and solid lines represent linear parameterizations from Jimenez et al. (2009) and Chang et al. (2010). Shaded rectangle represents typical range of ambient $\kappa_{\text {org }}$ and O/C values (Liu and Wang, 2010; Ng et al., 2010).

generated from naphthalene did not significantly change with increasing $\mathrm{OH}$ exposure, yielding an $(\mathrm{H} / \mathrm{C}) /(\mathrm{O} / \mathrm{C})$ slope of $-0.05 \pm 0.02$; similar trends were observed for SOA generated from naphthalene in a smog chamber (Chhabra et al., 2011). For SOA generated from glyoxal, the $(\mathrm{H} / \mathrm{C}) /(\mathrm{O} / \mathrm{C})$ slope was $-1.2 \pm 0.2$, consistent with addition of carboxylic acid groups towards formation of oxalic acid.

For several types of PAM-generated SOA, the $(\mathrm{H} / \mathrm{C}) /(\mathrm{O} / \mathrm{C})$ slope changes significantly over the course of oxidation. This evolution suggests that the reaction mechanism changed as the SOA became more oxidized. The changes in Van Krevelen slope are most pronounced for SOA generated from alkanes (Fig. 6a), where the slope increases from about -1.4 to -0.3 with increasing oxidation. Along with corresponding changes in $f_{43}$ and $f_{44}$, the observed changes in slope may indicate a transition in the oxidation reaction mechanism from carbonyl and acid/alcohol formation with minor fragmentation to acid formation with significant fragmentation. This possibility will be examined in future work.

$\mathrm{H} / \mathrm{C}$ and $\mathrm{O} / \mathrm{C}$ ratios of SOA generated from six of the precursors used in this work were also characterized in smog chamber studies (Chhabra et al., 2011). For example, at $\mathrm{O} / \mathrm{C}$ ratios ranging from 0.48 to 0.77 where our measurements overlap with Chhabra et al. (2011), the $\mathrm{H} / \mathrm{C}$ ratio for SOA generated from naphthalene ranged from 0.77 to 0.78 in the PAM reactor and 0.83 to 0.93 in the measurements of Chhabra et al. (2011). The agreement in $\mathrm{H} / \mathrm{C}$ ratios for SOA generated from isoprene is similar (1.6 to 1.7 in the PAM reactor and 1.5 to 1.6 in the measurements of Chhabra et al. for $\mathrm{O} / \mathrm{C}$ ratios ranging from 0.45 to 0.65 ).

\subsection{CCN hygroscopicity parameter $\left(\kappa_{\mathrm{org}}\right)$ of PAM-generated SOA and OPOA}

Many studies have measured $\kappa_{\text {org }} \approx 0$ for OPOA and $\kappa_{\text {org }} \approx$ 0.1 for SOA (e.g. Petters and Kreidenweis, 2007, and references therein). Experimental studies suggest that $\kappa_{\text {org }}$ depends on chemical composition and/or oxidation level of SOA/OPOA (George et al., 2009; Petters et al., 2009; Chang et al., 2010; Massoli et al., 2010; Engelhart et al., 2011), and the work presented here provides the most extensive evidence that oxidation level influences $\kappa_{\text {org }}$. Measurements of $\kappa_{\text {org }}$ were made for SOA and OPOA generated from the fourteen precursors listed in Table 1 . Figure 7 shows $\kappa_{\text {org }}$ as a function of $\mathrm{O} / \mathrm{C}$ ratio for PAM-generated SOA/OPOA (except for SOA generated from glyoxal, which is presented and discussed separately later in this section). Data shown in this figure were collected with both the c-ToF-AMS and HRToF-AMS. The results yielded values for the hygroscopicity parameter $\kappa_{\text {org }}$ ranging from $8.4 \times 10^{-4}$ to 0.28 for $\mathrm{O} / \mathrm{C}$ ratios 
that ranged from 0.05 to 1.42 , as well as $\kappa_{\text {org }}<6 \times 10^{-4}$ for unoxidized BES and lubricating oil particles. The shaded rectangle in Fig. 7 represents the typical range of ambient $\mathrm{O} / \mathrm{C}$ ratio and $\kappa_{\text {org }}$ values (Liu and Wang, 2010; Ng et al., 2010). The measured $\kappa_{\text {org }}$ for oxalic acid is also shown in Fig. 7, and is in agreement with published values ranging from 0.27 to 0.36 (Petters et al., 2009). Asa-Awuku et al. (2010) and Engelhart et al. (2011) measured $\kappa_{\text {org }}=0.30$ for the water-soluble fraction of smog-chamber-generated SOA. These results, coupled with the maximum observed $\kappa_{\text {org }}=0.28$ for PAM-generated SOA, suggest $\kappa_{\text {org }} \approx 0.30$ is an upper-bound value for $\kappa_{\text {org }}$.

The black dashed line in Fig. 7 represents a linear fit applied to the SOA/OPOA measurements; grey lines represent $\pm 1 \sigma$ confidence bands. The linear fit yields $\kappa_{\text {org }}=(0.18 \pm 0.04) \times \mathrm{O} / \mathrm{C}+0.03$ over the measured range of conditions. Figure 7 shows that $\kappa_{\text {org }}$ and $\mathrm{O} / \mathrm{C}$ ratio are positively correlated $\left(r^{2}=0.83\right)$. Obviously, level of oxidation is not the only factor that can affect $\kappa_{\text {org }}$. While this correlation is not currently understood at the molecular level, the dependence of $\kappa_{\text {org }}$ on $\mathrm{O} / \mathrm{C}$ ratio suggests that a simple, semiempirical parameterization of $\kappa_{\text {org }}$ and $\mathrm{O} / \mathrm{C}$ ratio can provide a first-order approach to better estimate $\kappa_{\text {org }}$ of OOA.

As is evident, for low $\mathrm{O} / \mathrm{C}$ ratios ranging from $\sim 0.05$ to 0.2 , the relationship between $\kappa_{\text {org }}$ and $\mathrm{O} / \mathrm{C}$ ratio is not encompassed by the linear fit shown in Fig. 7. Measurements that fall in this range of $\mathrm{O} / \mathrm{C}$ include OPOA generated from the heterogenous oxidation of BES and lubricating oil, and SOA generated from $n-\mathrm{C}_{17}$ (see Fig. 7 inset). This behavior suggests that for these low $\mathrm{O} / \mathrm{C}$ ratios, factors other than the level of oxidation may have an important influence on $\kappa_{\text {org }}$. The observed step from $\kappa_{\text {org }}=0.02$ to $\kappa_{\text {org }}=0.06$ at $\mathrm{O} / \mathrm{C}$ $\approx 0.15$ is a result that warrants further investigation in future studies.

As shown by the color symbols, the fitted line in Fig. 7 averages over a number of types of SOA/OPOA generated from both biogenic and anthropogenic precursors. These results can be compared to previous studies performed over a more limited range of conditions. Chang et al. (2010) measured $\kappa_{\text {org }}$ for ambient $\mathrm{OA}$ with $\mathrm{O} / \mathrm{C}$ ratios ranging from 0.3 to 0.6 . They proposed a linear parameterization of the form $\kappa_{\text {org }}=(0.29 \pm 0.05) \times \mathrm{O} / \mathrm{C}$ (assuming $\kappa_{\text {org }}=0$ for $\mathrm{O} / \mathrm{C}=0$ ). Massoli et al. (2010) measured $\kappa_{\text {org }}$ for PAMgenerated SOA with $\mathrm{O} / \mathrm{C}$ ratios ranging from 0.38 to 0.98 . Applying a linear fit to the data presented by Massoli et al. $(2010)$ yields $\kappa_{\text {org }}=(0.26 \pm 0.03) \times \mathrm{O} / \mathrm{C}$. Jimenez et al. (2009), Raatikainen et al. (2010) and Duplissy et al. (2011) showed $\kappa_{\text {org }}$ as a function of $\mathrm{O} / \mathrm{C}$ ratio for multiple smog chamber and field measurements; applying a linear fit to the data yields $\kappa_{\text {org }}=(0.37 \times \mathrm{O} / \mathrm{C})-0.09$. We note that $\kappa_{\text {org }}$ values presented in Raatikainen et al. (2010) and Duplissy et al. (2011) are derived from hygroscopic growth factor measurements, which tend to yield lower $\kappa_{\text {org }}$ values than corresponding CCN measurements (Massoli et al., 2010). The parameterizations from Jimenez et al. (2009) and Chang et al.

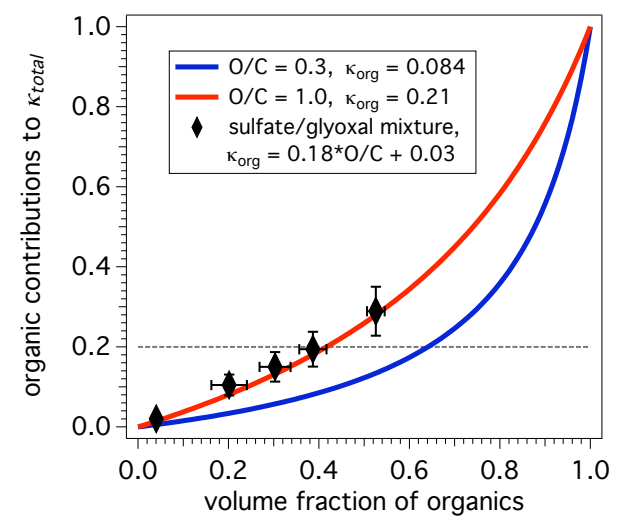

Fig. 8. Calculated contributions by OOA to $\kappa_{\text {total }}$ in mixtures of ammonium sulfate and OOA shown as a function of organics volume fraction. Blue and red lines represent calculated $\kappa$-values for mixtures of ammonium sulfate and OOA with $\mathrm{O} / \mathrm{C}$ ratios of 0.3 and 1.0, respectively. Black diamond symbols represent measured $\kappa$-values for a mixture of ammonium sulfate and glyoxal. Grey dashed line indicates level below which OOA contributions to $\kappa_{\text {total }}$ are considered insignificant $(<20 \%)$.

(2010) are shown in Fig. 7. In several studies, $\kappa_{\text {org }}$ was measured for SOA and OPOA generated in flow tubes and smog chambers (Huff Hartz et al., 2005; King et al., 2007; Prenni et al., 2007; George et al., 2009; Engelhart et al., 2011). In these studies, $\kappa_{\text {org }}$ values fall in the range observed in the present work. However, the range of $\mathrm{O} / \mathrm{C}$ ratios was not adequate for the formulation of a quantitative relationship with respect to $\kappa_{\text {org }}$.

In most cases, atmospheric aerosol is a mixture of organic and inorganic material, with soluble inorganics being significantly more hygroscopic than organics. In this regard, it is important to evaluate the $\kappa_{\text {org }}-\mathrm{O} / \mathrm{C}$ parameterization shown in Fig. 7 in the context of inorganics mixed with OOA. Figure 8 shows the calculated fractional contribution of OOA to the $\kappa$-values of a mixture of ammonium sulfate and OOA $\left(\kappa_{\text {total }} ; \kappa_{\text {sulfate }}=0.6\right)$ as a function of the volume fraction of organics, assuming linear volume-weighted OOA and sulfate contributions to $\kappa_{\text {total }}$ (King et al., 2007, 2010; Dusek et al., 2010; Prisle et al., 2010) and complete solubility of the organics and inorganics (Petters and Kreidenweis, 2007):

$$
f_{\kappa_{\text {total }, \text { OOA }}}=\frac{v_{\text {org }} \kappa_{\text {org }}}{v_{\text {org }} \kappa_{\text {org }}+\left(1-v_{\text {org }}\right) \kappa_{\text {sulfate }}}
$$

Where $f_{\kappa_{\text {total, OOA }}}$ is the fractional contribution of OOA to $\kappa_{\text {total }}$ and $\nu_{\text {org }}$ is the volume fractions of organics in solution. Two lines are shown for theoretical mixtures containing sulfate and OOA with $\mathrm{O} / \mathrm{C}$ ratios of 0.3 and 1.0, respectively (the most common range of $\mathrm{O} / \mathrm{C}$ in ambient OOA). Data for a mixture of ammonium sulfate and glyoxal are also shown (diamond symbols), which were derived from measured mixture $\kappa$-values. For these data, the $\mathrm{O} / \mathrm{C}$ ratio derived from HR-ToF-AMS measurements increased from 1.06 to 
1.50 as a function of $\mathrm{OH}$ exposure, and corresponding $\kappa_{\mathrm{org}}-$ values were calculated using the fit shown in Fig. 7. The organic volume fraction of SOA generated from glyoxal also decreased from 0.53 to 0.04 as a function of oxidation. This suggests that the unoxidized glyoxal oligomers undergo fragmentation reactions that (1) increase the $\mathrm{O} / \mathrm{C}$ ratio and (2) result in evaporation of some organic aerosol mass.

The $\kappa_{\text {org }}-\mathrm{O} / \mathrm{C}$ parameterization described previously was used to calculate $\kappa_{\text {org }}$ for the two theoretical OOA/sulfate mixtures and for SOA generated from glyoxal. As is evident from Fig. 8, for an O/C ratio of 0.3, OOA contributions to $\kappa$ are significant $(>20 \%)$ when the organic fraction is greater than 0.6. For an $\mathrm{O} / \mathrm{C}$ ratio of 1.0, OOA contributions to $\kappa$ are significant when the organic fraction is greater than 0.4. Prenni et al. (2007) showed that SOA contributions to $\kappa$-values for mixed SOA-sulfate particles were significant when the organic fraction was greater than 0.6; however the $\mathrm{O} / \mathrm{C}$ ratio in those experiments was not available. Calculations in Fig. 8 therefore indicate the approximate range of $\mathrm{O} / \mathrm{C}$ ratios and organic volume fractions where explicit treatment of $\kappa_{\text {org }}$ as a function of $\mathrm{O} / \mathrm{C}$ ratio is necessary.

\section{Summary}

Our results show that PAM-generated SOA and OPOA can reproduce and extend beyond the range of $f_{44}-f_{43}$ composition observed in smog chamber and ambient studies. Several types of PAM-generated SOA displayed $f_{43}$ curvature as a function of $\mathrm{OH}$ exposure, with $f_{43}$ initially increasing prior to decreasing with continued oxidation. This trend suggests a progression from earlier-generation oxidation products containing higher $f_{43}$ (specifically, $\mathrm{C}_{2} \mathrm{H}_{3} \mathrm{O}^{+}$ions) towards latergeneration oxidation products containing lower $f_{43}$.

Mixing PAM-generated SOA containing low and high $f_{43}$ produced SOA with intermediate $f_{43}$. The $f_{44}-f_{43}$ composition of ambient OOA may provide information about precursor structure(s). Measurements from the present work suggest that OOA lying towards the left edge of the ambient $f_{44}-f_{43}$ triangle may be influenced by nonmethylated aromatic precursors and/or glyoxal. Similarly, OOA that lies towards the right edge of the triangle may be influenced by methylated aromatic, biogenic, and/or alkane precursors. Inside the ambient $f_{44}-f_{43}$ triangle, OOA may be influenced by a mixture of precursors that individually form OOA lying towards both the left and right edges of the triangle.

Van Krevelen diagrams of PAM-generated SOA/OPOA showed that the $\mathrm{H} / \mathrm{C}$ ratio usually decreased and the $\mathrm{O} / \mathrm{C}$ ratio increased with oxidation. The corresponding $(\mathrm{H} / \mathrm{C}) /(\mathrm{O} / \mathrm{C})$ slopes suggest an oxidation mechanism involving formation of carboxylic acids concurrent with fragmentation of carboncarbon bonds, which is consistent with ambient OOA measurements. The $\mathrm{H} / \mathrm{C}$ and $\mathrm{O} / \mathrm{C}$ ratios of SOA/OPOA generated from naphthalene, glyoxal, and lubricating oil evolved at rates that were different from the other systems examined, possibly indicating different oxidation mechanisms. The position of OA in Van Krevelen diagrams may provide information about precursor composition and reaction mechanism. For example, ambient HOA PMF factors presented in $\mathrm{Ng}$ et al. (2011a) have $\mathrm{H} / \mathrm{C}$ ratios ranging from 1.5 to 2.0 and are characterized by a Van Krevelen slope of approximately -2 . These observations, combined with our laboratory measurements, suggest oxidation of alkane precursors forms OA with carbonyl functional groups.

The work presented here provides the most extensive set of CCN-derived hygroscopicity measurements of laboratorygenerated SOA and OPOA. The hygroscopicity parameter $\kappa_{\text {org }}$ can be represented by a linear function of the $\mathrm{O} / \mathrm{C}$ ratio as $\kappa_{\text {org }}=(0.18 \pm 0.04) \times \mathrm{O} / \mathrm{C}+0.03$. Parameterizations in this form may be implemented in climate models because the $\mathrm{O} / \mathrm{C}$ ratio of organic aerosols is easily measured, whereas other parameters relevant to $\kappa$-Köhler theory are difficult to obtain. Therefore, the $\mathrm{O} / \mathrm{C}$ ratio of OOA may represent a convenient surrogate for other underlying parameters that govern the Köhler behavior of the OOA.

\section{Supplementary material related to this article is available online at: \\ http://www.atmos-chem-phys.net/11/8913/2011/ acp-11-8913-2011-supplement.pdf.}

Acknowledgements. We thank Tiffany Samuelson, Kenneth Christian, and Diana van Duin (Pennsylvania State University) for preparing compressed VOC canisters. We thank Jon Franklin and Scott Herndon (ARI) for building permeation tube ovens used in the present work, and are grateful to $\mathrm{Nga}$ Lee $\mathrm{Ng}$ and Manjula Canagaratna (ARI) for helpful discussions. We also thank the reviewers and the editor for useful feedback on the discussions paper. This research was supported by the Office of Science (BER), Department of Energy (Atmospheric Science Program) grant No. DE-FG02-05ER63995, the Atmospheric Chemistry Program of the National Science Foundation grants No. ATM-0525355, AGS-0854916, and AGS-0904292, and the National Oceanic and Atmospheric Administration Climate Program grant No. NA09OAR4310125 to Boston College and Aerodyne Research, Inc.

Edited by: B. Ervens

\section{References}

Aiken, A., DeCarlo, P., Kroll, J., Worsnop, D., Huffman, J., Docherty, K., Ulbrich, I., Mohr, C., Kimmel, J., and Sueper, D.: $\mathrm{O} / \mathrm{C}$ and $\mathrm{OM} / \mathrm{OC}$ ratios of primary, secondary, and ambient organic aerosols with high-resolution time-of-flight aerosol mass spectrometry, Environ. Sci. Technol., 42, 4478-4485, 2008.

Aiken, A. C., de Foy, B., Wiedinmyer, C., DeCarlo, P. F., Ulbrich, I. M., Wehrli, M. N., Szidat, S., Prevot, A. S. H., Noda, J., Wacker, L., Volkamer, R., Fortner, E., Wang, J., Laskin, A., Shutthanandan, V., Zheng, J., Zhang, R., Paredes-Miranda, G., Arnott, W. P., Molina, L. T., Sosa, G., Querol, X., and Jimenez, 
J. L.: Mexico City aerosol analysis during MILAGRO using high resolution aerosol mass spectrometry at the urban supersite (T0) - Part 2: Analysis of the biomass burning contribution and the non-fossil carbon fraction, Atmos. Chem. Phys., 10, 5315-5341, doi:10.5194/acp-10-5315-2010, 2010.

Asa-Awuku, A., Engelhart, G. J., Lee, B. H., Pandis, S. N., and Nenes, A.: Relating CCN activity, volatility, and droplet growth kinetics of $\beta$-caryophyllene secondary organic aerosol, Atmos. Chem. Phys., 9, 795-812, doi:10.5194/acp-9-795-2009, 2009.

Asa-Awuku, A., Nenes, A., Gao, S., Flagan, R. C., and Seinfeld, J. H.: Water-soluble SOA from Alkene ozonolysis: composition and droplet activation kinetics inferences from analysis of CCN activity, Atmos. Chem. Phys., 10, 1585-1597, doi:10.5194/acp10-1585-2010, 2010.

Carlton, A., Turpin, B., Altieri, K., Seitzinger, S., Reff, A., Lim, H., and Ervens, B.: Atmospheric oxalic acid and SOA production from glyoxal: results of aqueous photooxidation experiments, Atmos. Environ., 41, 7588-7602, 2007.

Chan, A. W. H., Kautzman, K. E., Chhabra, P. S., Surratt, J. D., Chan, M. N., Crounse, J. D., Kürten, A., Wennberg, P. O., Flagan, R. C., and Seinfeld, J. H.: Secondary organic aerosol formation from photooxidation of naphthalene and alkylnaphthalenes: implications for oxidation of intermediate volatility organic compounds (IVOCs), Atmos. Chem. Phys., 9, 3049-3060, doi:10.5194/acp-9-3049-2009, 2009.

Chang, R. Y.-W., Slowik, J. G., Shantz, N. C., Vlasenko, A., Liggio, J., Sjostedt, S. J., Leaitch, W. R., and Abbatt, J. P. D.: The hygroscopicity parameter $(\kappa)$ of ambient organic aerosol at a field site subject to biogenic and anthropogenic influences: relationship to degree of aerosol oxidation, Atmos. Chem. Phys., 10, 50475064, doi:10.5194/acp-10-5047-2010, 2010.

Chhabra, P. S., Flagan, R. C., and Seinfeld, J. H.: Elemental analysis of chamber organic aerosol using an aerodyne high-resolution aerosol mass spectrometer, Atmos. Chem. Phys., 10, 4111-4131, doi:10.5194/acp-10-4111-2010, 2010.

Chhabra, P. S., Ng, N. L., Canagaratna, M. R., Corrigan, A. L., Russell, L. M., Worsnop, D. R., Flagan, R. C., and Seinfeld, J. H.: Elemental composition and oxidation of chamber organic aerosol, Atmos. Chem. Phys. Discuss., 11, 10305-10342, doi:10.5194/acpd-11-10305-2011, 2011.

de Gouw, J. A., Middlebrook, A. M., Warneke, C., Ahmadov, R., Atlas, E. L., Bahreini, R., Blake, D. R., Brock, C. A., Brioude, J., Fahey, D. W., Fehsenfeld, F. C., Holloway, J. S., Henaff, M. L., Lueb, R. A., McKeen, S. A., Meagher, J. F., Murphy, D. M., Paris, C., Parrish, D. D., Perring, A. E., Pollack, I. B., Ravishankara, A. R., Robinson, A. L., Ryerson, T. B., Schwarz, J. P., Spackman, J. R., Srinivasan, A., and Watts, L. A.: Organic aerosol formation downwind from the Deepwater Horizon oil spill, Science, 331, 1295-1299, doi:10.1126/science.1200320, 2011.

DeCarlo, P. F., Kimmel, J. R., Trimborn, A., Northway, M. J., Jayne, J. T., Aiken, A. C., Gonin, M., Fuhrer, K., Horvath, T., Docherty, K. S., Worsnop, D. R., and Jimenez, J. L.: Field-deployable, high-resolution, time-of-flight aerosol mass spectrometer, Anal. Chem., 78, 8281-8289, doi:10.1021/ac061249n, 2006.

DeCarlo, P. F., Ulbrich, I. M., Crounse, J., de Foy, B., Dunlea, E. J., Aiken, A. C., Knapp, D., Weinheimer, A. J., Campos, T., Wennberg, P. O., and Jimenez, J. L.: Investigation of the sources and processing of organic aerosol over the Central Mex- ican Plateau from aircraft measurements during MILAGRO, Atmos. Chem. Phys., 10, 5257-5280, doi:10.5194/acp-10-52572010, 2010.

Drewnick, F., Hings, S. S., DeCarlo, P. F., Jayne, J. T., Gonin, M., Fuhrer, K., Weimer, S., Jimenez, J. L., Demerjian, K. L., Borrmann, S., and Worsnop, D. R.: A new time-of-flight aerosol mass spectrometer (TOF-AMS) - instrument description and first field deployment, Aerosol Sci. Technol., 39, 637-658, doi:10.1080/02786820500182040, 2005.

Duplissy, J., DeCarlo, P. F., Dommen, J., Alfarra, M. R., Metzger, A., Barmpadimos, I., Prevot, A. S. H., Weingartner, E., Tritscher, T., Gysel, M., Aiken, A. C., Jimenez, J. L., Canagaratna, M. R., Worsnop, D. R., Collins, D. R., Tomlinson, J., and Baltensperger, U.: Relating hygroscopicity and composition of organic aerosol particulate matter, Atmos. Chem. Phys., 11, 1155-1165, doi:10.5194/acp-11-1155-2011.

Dusek, U., Frank, G. P., Curtius, J., Drewnick, F., Schneider, J., Kürten, A., Rose, D., Andreae, M. O., Borrmann, S., and Pöschl, U.: Enhanced organic mass fraction and decreased hygroscopicity of cloud condensation nuclei $(\mathrm{CCN})$ during new particle formation events, Geophys. Res. Lett., 37, L03804, doi:10.1029/2009GL040930, 2010

Engelhart, G. J., Moore, R. H., Nenes, A., and Pandis, S. N.: Cloud condensation nuclei activity of isoprene secondary organic aerosol, J. Geophys. Res., 116, D02207, doi:10.1029/2010JD014706, 2011.

Ervens, B., Feingold, G., Frost, G. J., and Kreidenweis, S. M.: A modeling study of aqueous production of dicarboxylic acids: 1 . Chemical pathways and speciated organic mass production, J. Geophys. Res., 109, D15205, doi:10.1029/2003JD004387, 2004.

Fuzzi, S., Andreae, M. O., Huebert, B. J., Kulmala, M., Bond, T. C., Boy, M., Doherty, S. J., Guenther, A., Kanakidou, M., Kawamura, K., Kerminen, V.-M., Lohmann, U., Russell, L. M., and Pschl, U.: Critical assessment of the current state of scientific knowledge, terminology, and research needs concerning the role of organic aerosols in the atmosphere, climate, and global change, Atmos. Chem. Phys., 6, 2017-2038, doi:10.5194/acp-62017-2006, 2006.

George, I. J., Chang, R. Y. W., Danov, V., Vlasenko, A., and Abbatt, J. P. D.: Modification of cloud condensation nucleus activity of organic aerosols by hydroxyl radical heterogeneous oxidation, Atmos. Environ., 43, 5038-5045, doi:10.1016/j.atmosenv.2009.06.043, 2009.

George, I. J., and Abbatt, J. P. D.: Chemical evolution of secondary organic aerosol from $\mathrm{OH}$-initiated heterogeneous oxidation, Atmos. Chem. Phys., 10, 5551-5563, doi:10.5194/acp-10-55512010, 2010.

Ghan, S. and Schwartz, S.: Aerosol properties and processes, B. Am. Meteorol. Soc, 88, 1059-1083, 2007.

Hallquist, M., Wenger, J. C., Baltensperger, U., Rudich, Y., Simpson, D., Claeys, M., Dommen, J., Donahue, N. M., George, C., Goldstein, A. H., Hamilton, J. F., Herrmann, H., Hoffmann, T., Iinuma, Y., Jang, M., Jenkin, M. E., Jimenez, J. L., Kiendler-Scharr, A., Maenhaut, W., McFiggans, G., Mentel, Th. F., Monod, A., Prévôt, A. S. H., Seinfeld, J. H., Surratt, J. D., Szmigielski, R., and Wildt, J.: The formation, properties and impact of secondary organic aerosol: current and emerging issues, Atmos. Chem. Phys., 9, 5155-5236, doi:10.5194/acp-95155-2009, 2009. 
He, L.-Y., Lin, Y., Huang, X.-F., Guo, S., Xue, L., Su, Q., Hu, M., Luan, S.-J., and Zhang, Y.-H.: Characterization of highresolution aerosol mass spectra of primary organic aerosol emissions from Chinese cooking and biomass burning, Atmos. Chem. Phys., 10, 11535-11543, doi:10.5194/acp-10-11535-2010, 2010.

Heald, C. L., Kroll, J. H., Jimenez, J. L., Docherty, K. S., Decarlo, P. F., Aiken, A. C., Chen, Q., Martin, S. T., Farmer, D. K., and Artaxo, P.: A simplified description of the evolution of organic aerosol composition in the atmosphere, Geophys. Res. Lett., 37, L08803, doi:10.1029/2010GL042737, 2010.

Hildebrandt, L., Engelhart, G. J., Mohr, C., Kostenidou, E., Lanz, V. A., Bougiatioti, A., DeCarlo, P. F., Prevot, A. S. H., Baltensperger, U., Mihalopoulos, N., Donahue, N. M., and Pandis, S. N.: Aged organic aerosol in the Eastern Mediterranean: the Finokalia Aerosol Measurement Experiment - 2008, Atmos. Chem. Phys., 10, 4167-4186, doi:10.5194/acp-10-4167-2010, 2010.

Huff Hartz, K. E., Rosenorn, T., Ferchak, S., Raymond, T., Bilde, M., Donahue, N., and Pandis, S.: Cloud condensation nuclei activation of monoterpene and sesquiterpene secondary organic aerosol, J. Geophys. Res., 110, D14208, doi:10.1029/2004JD005754, 2005.

Huffman, J. A., Docherty, K. S., Aiken, A. C., Cubison, M. J., Ulbrich, I. M., DeCarlo, P. F., Sueper, D., Jayne, J. T., Worsnop, D. R., Ziemann, P. J., and Jimenez, J. L.: Chemically-resolved aerosol volatility measurements from two megacity field studies, Atmos. Chem. Phys., 9, 7161-7182, doi:10.5194/acp-9-71612009, 2009.

Huffman, J. A., Ziemann, P., Jayne, J., Worsnop, D., and Jimenez, J.: Development and characterization of a fast-stepping/scanning thermodenuder for chemically-resolved aerosol volatility measurements, Aerosol Sci. Technol., 42, 395407, doi:10.1080/02786820802104981, 2008.

Jimenez, J. L., Canagaratna, M. R., Donahue, N. M., Prevot, A. S. H., Zhang, Q., Kroll, J. H., Decarlo, P. F., Allan, J. D., Coe, H., Ng, N. L., Aiken, A. C., Docherty, K. S., Ulbrich, I. M., Grieshop, A. P., Robinson, A. L., Duplissy, J., Smith, J. D., Wilson, K. R., Lanz, V. A., Hueglin, C., Sun, Y. L., Tian, J., Laaksonen, A., Raatikainen, T., Rautiainen, J., Vaattovaara, P., Ehn, M., Kulmala, M., Tomlinson, J. M., Collins, D. R., Cubison, M. J., Dunlea, J., Huffman, J. A., Onasch, T. B., Alfarra, M. R., Williams, P. I., Bower, K., Kondo, Y., Schneider, J., Drewnick, F., Borrmann, S., Weimer, S., Demerjian, K., Salcedo, D., Cottrell, L., Griffin, R., Takami, A., Miyoshi, T., Hatakeyama, S., Shimono, A., Sun, J. Y., Zhang, Y. M., Dzepina, K., Kimmel, J. R., Sueper, D., Jayne, J. T., Herndon, S. C., Trimborn, A. M., Williams, L. R., Wood, E. C., Middlebrook, A. M., Kolb, C. E., Baltensperger, U., and Worsnop, D. R.: Evolution of organic aerosols in the atmosphere, Science, 326, 1525-1529, doi:10.1126/science.1180353, 2009.

Kanakidou, M., Seinfeld, J. H., Pandis, S. N., Barnes, I., Dentener, F. J., Facchini, M. C., Van Dingenen, R., Ervens, B., Nenes, A., Nielsen, C. J., Swietlicki, E., Putaud, J. P., Balkanski, Y., Fuzzi, S., Horth, J., Moortgat, G. K., Winterhalter, R., Myhre, C. E. L., Tsigaridis, K., Vignati, E., Stephanou, E. G., and Wilson, J.: Organic aerosol and global climate modelling: a review, Atmos. Chem. Phys., 5, 1053-1123, doi:10.5194/acp-5-1053-2005, 2005.

Kang, E., Root, M. J., Toohey, D. W., and Brune, W. H.: Introduc- ing the concept of Potential Aerosol Mass (PAM), Atmos. Chem. Phys., 7, 5727-5744, doi:10.5194/acp-7-5727-2007, 2007.

King, S. M., Rosenoern, T., Shilling, J. E., Chen, Q., Wang, Z., Biskos, G., McKinney, K. A., Pöschl, U., and Martin, S. T.: Cloud droplet activation of mixed organic-sulfate particles produced by the photooxidation of isoprene, Atmos. Chem. Phys., 10, 3953-3964, doi:10.5194/acp-10-3953-2010, 2010.

King, S. M., Rosenoern, T., Shilling, J. E., Chen, Q., and Martin, S. T.: Cloud condensation nucleus activity of secondary organic aerosol particles mixed with sulfate, Geophys. Res. Lett., 34, L24806, doi:10.1029/2007GL030390, 2007.

Kroll, J. H., Ng, N. L., Murphy, S. M., Flagan, R. C., and Seinfeld, J. H.: Secondary organic aerosol formation from isoprene photooxidation, Environ. Sci. Technol., 40, 1869-1877, 2006.

Kroll, J. H. and Seinfeld, J. H.: Chemistry of secondary organic aerosol: Formation and evolution of low-volatility organics in the atmosphere, Atmos. Environ., 42, 3593-3624, 2008.

Kroll, J. H., Smith, J. D., Che, D. L., Kessler, S. H., Worsnop, D. R., and Wilson, K. R.: Measurement of fragmentation and functionalization pathways in the heterogeneous oxidation of oxidized organic aerosol, Phys. Chem. Chem. Phys., 11, 8005, doi:10.1039/b905289e, 2009.

Kroll, J. H., Donahue, N. M., Jimenez, J. L., Kessler, S. H., Canagaratna, M. R., Wilson, K. R., Altieri, K. E., Mazzoleni, L. R., Wozniak, A. S., Bluhm, H., Mysak, E. R., Smith, J. D., Kolb, C. E., and Worsnop, D. R.: Carbon oxidation state as a metric for describing the chemistry of atmospheric organic aerosol, Nature Chem., 3, 133-139, doi:10.1038/nchem.948, 2011.

Lambe, A. T., Miracolo, M. A., Hennigan, C. J., Robinson, A. L., and Donahue, N. M.: Effective Rate Constants and Uptake Coefficients for the Reactions of Organic Molecular Markers (nAlkanes, Hopanes, and Steranes) in Motor Oil and Diesel Primary Organic Aerosols with Hydroxyl Radicals, Environ Sci. Technol., 43, 8794-8800, 2009.

Lambe, A. T., Ahern, A. T., Williams, L. R., Slowik, J. G., Wong, J. P. S., Abbatt, J. P. D., Brune, W. H., Ng, N. L., Wright, J. P., Croasdale, D. R., Worsnop, D. R., Davidovits, P., and Onasch, T. B.: Characterization of aerosol photooxidation flow reactors: heterogeneous oxidation, secondary organic aerosol formation and cloud condensation nuclei activity measurements, Atmos. Meas. Tech., 4, 445-461, doi:10.5194/amt-4-445-2011, 2011.

Lance, S., Medina, J., Smith, J., and Nenes, A.: Mapping the operation of the DMT continuous flow CCN counter, Aerosol Sci. Technol., 40, 242-254, doi:10.1080/02786820500543290, 2006.

Lanz, V. A., Alfarra, M. R., Baltensperger, U., Buchmann, B., Hueglin, C., and Prévôt, A. S. H.: Source apportionment of submicron organic aerosols at an urban site by factor analytical modelling of aerosol mass spectra, Atmos. Chem. Phys., 7, 1503-1522, doi:10.5194/acp-7-1503-2007, 2007.

Lee, A. K. Y., Herckes, P., Leaitch, W. R., Macdonald, A. M., and Abbatt, J. P. D.: Aqueous $\mathrm{OH}$ oxidation of ambient organic aerosol and cloud water organics: formation of highly oxidized products, Geophys. Res. Lett., 38, L11805, doi:10.1029/2011GL047439, 2011.

Liu, X. and Wang, J.: How important is organic aerosol hygroscopicity to aerosol indirect forcing?, Environ. Res. Lett., 5, 044010 , doi:10.1088/1748-9326/5/4/044010, 2010.

Mao, J., Ren, X., Brune, W. H., Olson, J. R., Crawford, J. H., Fried, A., Huey, L. G., Cohen, R. C., Heikes, B., Singh, H. B., Blake, 
D. R., Sachse, G. W., Diskin, G. S., Hall, S. R., and Shetter, R. E.: Airborne measurement of $\mathrm{OH}$ reactivity during INTEX-B, Atmos. Chem. Phys., 9, 163-173, doi:10.5194/acp-9-163-2009, 2009.

Matsunaga, A. and Ziemann, P. J.: Gas-wall partitioning of organic compounds in a teflon film chamber and potential effects on reaction product and aerosol yield measurements, Aerosol Sci. Tech., 44(10), 881-892, 2010.

Massoli, P., Lambe, A. T., Ahern, A. T., Williams, L. R., Ehn, M., Mikkilä, J., Canagaratna, M. R., Brune, W. H., Onasch, T. B., Jayne, J. T., Petäjä, T., Kulmala, M., Laaksonen, A., Kolb, C. E., Davidovits, P., and Worsnop, D. R.: Relationship between aerosol oxidation level and hygroscopic properties of laboratory generated secondary organic aerosol (SOA) particles, Geophys. Res. Lett., 37, L24801, doi:10.1029/2010GL045258, 2010.

Mazzoleni, L., Ehrmann, B., Shen, X., Marshall, A., and Collett Jr., J. L.: Water-soluble atmospheric organic matter in fog: exact masses and chemical formula identification by ultrahighresolution Fourier transform ion cyclotron resonance mass spectrometry, Environ. Sci. Technol., 44, 3690-3697, 2010.

McKinley, J.: Permeation tubes: A simple path to very complex gas mixtures, Gases \& Instrumentation, 22-26, available online at: www.gasesmag.com, 2008.

Miracolo, M. A., Presto, A. A., Lambe, A. T., Hennigan, C. J., Donahue, N. M., Kroll, J. H., Worsnop, D. R., and Robinson, A. L..: Photo-oxidation of low-volatility organics found in motor vehicle emissions: Production and chemical evolution of organic aerosol mass, Environ. Sci. Technol., 44, 1638-1643, 2010.

Morgan, W. T., Allan, J. D., Bower, K. N., Highwood, E. J., Liu, D., McMeeking, G. R., Northway, M. J., Williams, P. I., Krejci, R., and Coe, H.: Airborne measurements of the spatial distribution of aerosol chemical composition across Europe and evolution of the organic fraction, Atmos. Chem. Phys., 10, 4065-4083, doi:10.5194/acp-10-4065-2010, 2010.

Ng, N. L., Canagaratna, M. R., Zhang, Q., Jimenez, J. L., Tian, J., Ulbrich, I. M., Kroll, J. H., Docherty, K. S., Chhabra, P. S., Bahreini, R., Murphy, S. M., Seinfeld, J. H., Hildebrandt, L., Donahue, N. M., DeCarlo, P. F., Lanz, V. A., Prvt, A. S. H., Dinar, E., Rudich, Y., and Worsnop, D. R.: Organic aerosol components observed in Northern Hemispheric datasets from Aerosol Mass Spectrometry, Atmos. Chem. Phys., 10, 46254641, doi:10.5194/acp-10-4625-2010, 2010.

Ng, N. L., Canagaratna, M. R., Jimenez, J. L., Zhang, Q., Ulbrich, I. M., and Worsnop, D. R.: Real-time methods for estimating organic component mass concentrations from aerosol mass spectrometer data, Environ. Sci. Technol., 45, 910-916, 2011 a.

Ng, N. L., Canagaratna, M. R., Jimenez, J. L., Chhabra, P. S., Seinfeld, J. H., and Worsnop, D. R.: Changes in organic aerosol composition with aging inferred from aerosol mass spectra, Atmos. Chem. Phys., 11, 6465-6474, doi:10.5194/acp-11-64652011, 2011b.

Nguyen, T., Roach, P., Laskin, J., Laskin, A., and Nizkorodov, S.: Effect of humidity on the composition of isoprene photooxidation secondary organic aerosol, Atmos. Chem. Phys., 11, 69316944, doi:10.5194/acp-11-6931-2011, 2011.

Nishino, N., Arey, J., and Atkinson, R.: Yields of glyoxal and ringcleavage co-products from the $\mathrm{OH}$ radical-initiated reactions of naphthalene and selected alkylnaphthalenes, Environ. Sci. Technol., 43, 8554-8560, 2009.
Nishino, N., Arey, J., and Atkinson, R.: Formation yields of glyoxal and methylglyoxal from the gas-phase $\mathrm{OH}$ radical-initiated reactions of toluene, xylenes, and trimethylbenzenes as a function of $\mathrm{NO}_{2}$ concentration, J. Phys. Chem. A, 114, 10140-10147, 2010.

Paatero, P. and Tapper, U.: Positive Matrix Factorization: A nonnegative factor model with optimal utilization of error estimates of data values, Environmetrics, 5, 111-126, 1994.

Petters, M. D. and Kreidenweis, S. M.: A single parameter representation of hygroscopic growth and cloud condensation nucleus activity, Atmos. Chem. Phys., 7, 1961-1971, doi:10.5194/acp-71961-2007, 2007.

Petters, M. D., Prenni, A. J., Kreidenweis, S. M., DeMott, P. J., Matsunaga, A., Lim, Y. B., and Ziemann, P. J.: Chemical aging and the hydrophobic-to-hydrophilic conversion of carbonaceous aerosol, Geophys. Res. Lett., 33, L24806, doi:10.1029/2006GL027249, 2006.

Petters, M. D., Kreidenweis, S. M., Prenni, A. J., Sullivan, R. C., Carrico, C. M., Koehler, K. A., and Ziemann, P. J.: Role of molecular size in cloud droplet activation, Geophys. Res. Lett., 36, L22801, doi:10.1029/2009GL040131, 2009.

Poulain, L., Wu, Z., Petters, M. D., Wex, H., Hallbauer, E., Wehner, B., Massling, A., Kreidenweis, S. M., and Stratmann, F.: Towards closing the gap between hygroscopic growth and $\mathrm{CCN}$ activation for secondary organic aerosols - Part 3: Influence of the chemical composition on the hygroscopic properties and volatile fractions of aerosols, Atmos. Chem. Phys., 10, 37753785, doi:10.5194/acp-10-3775-2010, 2010.

Prenni, A. J., Petters, M. D., Kreidenweis, S. M., DeMott, P. J., and Ziemann, P. J.: Cloud droplet activation of secondary organic aerosol, J. Geophys. Res., 112, D10223, doi:10.1029/2006JD007963, 2007.

Presto, A. A., Miracolo, M. A., Kroll, J. H., Worsnop, D. R., Robinson, A. L., and Donahue, N. M.: Intermediate-volatility organic compounds: a potential source of ambient oxidized organic aerosol, Environ. Sci. Technol., 43, 4744-4749, 2009.

Prisle, N. L., Raatikainen, T., Laaksonen, A., and Bilde, M.: Surfactants in cloud droplet activation: mixed organic-inorganic particles, Atmos. Chem. Phys., 10, 5663-5683, doi:10.5194/acp-105663-2010, 2010.

Raatikainen, T., Vaattovaara, P., Tiitta, P., Miettinen, P., Rautiainen, J., Ehn, M., Kulmala, M., Laaksonen, A., and Worsnop, D. R.: Physicochemical properties and origin of organic groups detected in boreal forest using an aerosol mass spectrometer, Atmos. Chem. Phys., 10, 2063-2077, doi:10.5194/acp-10-20632010, 2010.

Renbaum, L. H. and Smith, G. D.: Artifacts in measuring aerosol uptake kinetics: the roles of time, concentration and adsorption, Atmos. Chem. Phys., 11, 6881-6693, doi:10.5194/acp-11-68812011, 2011.

Roberts, G. C. and Nenes, A.: A continuous-flow streamwise thermal-gradient $\mathrm{CCN}$ chamber for atmospheric measurements, Aerosol Sci. Technol., 39, 206-221, doi:10.1080/027868290913988, 2005.

Robinson, A. L., Donahue, N. M., Shrivastava, M. K., Weitkamp, E. A., Sage, A. M., Grieshop, A. P., Lane, T. E., Pierce, J. R., and Pandis, S. N.: Rethinking organic aerosols: semivolatile emissions and photochemical aging, Science, 315, 1259-1262, doi:10.1126/science.1133061, 2007.

Shilling, J., King, S., Mochida, M., Worsnop, D., and Martin, S.: 
Mass spectral evidence that small changes in composition caused by oxidative aging processes alter aerosol CCN properties, J. Phys. Chem. A, 111, 3358-3368, 2007.

Sorooshian, A., Varutbangkul, V., Brechtel, F. J., Ervens, B., Feingold, G., Bahreini, R., Murphy, S. M., Holloway, J. S., Atlas, E. L., Buzorius, G., Jonsson, H., Flagan, R. C., and Seinfeld, J. H.: Oxalic acid in clear and cloudy atmospheres: analysis of data from International Consortium for Atmospheric Research on Transport and Transformation 2004, J. Geophys. Res., 111, D23S45, doi:10.1029/2005JD006880, 2006.

Takegawa, N., Miyakawa, T., Kawamura, K., and Kondo, Y.: Contribution of selected dicarboxylic and $\omega$-oxocarboxylic acids in ambient aerosol to the $\mathrm{m} / \mathrm{z}, 44$ signal of an Aerodyne aerosol mass spectrometer, Aerosol Sci. Technol., 41, 418-437, doi:10.1080/02786820701203215, 2007.

Ulbrich, I., Lechner, M., and Jimenez, J.: AMS Spectral Database, available online at: http://cires.colorado.edu/jimenez-group/ AMSsd/, last access: 7 April 2011.

Ulbrich, I. M., Canagaratna, M. R., Zhang, Q., Worsnop, D. R., and Jimenez, J. L.: Interpretation of organic components from Positive Matrix Factorization of aerosol mass spectrometric data, Atmos. Chem. Phys., 9, 2891-2918, doi:10.5194/acp-9-2891-2009, 2009.

Krevelen, D. V.: Graphical-statistical method for the study of structure and reaction processes of coal, Fuel, 24, 269-284, 1950.

Varutbangkul, V., Brechtel, F. J., Bahreini, R., Ng, N. L., Keywood, M. D., Kroll, J. H., Flagan, R. C., Seinfeld, J. H., Lee, A., and Goldstein, A. H.: Hygroscopicity of secondary organic aerosols formed by oxidation of cycloalkenes, monoterpenes, sesquiterpenes, and related compounds, Atmos. Chem. Phys., 6, 23672388, doi:10.5194/acp-6-2367-2006, 2006.
Volkamer, R., Platt, U., and Wirtz, K.: Primary and secondary glyoxal formation from aromatics: experimental evidence for the bicycloalkyl-radical pathway from benzene, toluene, and pxylene, J. Phys. Chem. A, 105, 7865-7874, 2001.

Wang, J., Cubison, M. J., Aiken, A. C., Jimenez, J. L., and Collins, D. R.: The importance of aerosol mixing state and size-resolved composition on $\mathrm{CCN}$ concentration and the variation of the importance with atmospheric aging of aerosols, Atmos. Chem. Phys., 10, 7267-7283, doi:10.5194/acp-10-7267-2010, 2010.

Wozniak, A. S., Bauer, J. E., Sleighter, R. L., Dickhut, R. M., and Hatcher, P. G.: Technical Note: Molecular characterization of aerosol-derived water soluble organic carbon using ultrahigh resolution electrospray ionization Fourier transform ion cyclotron resonance mass spectrometry, Atmos. Chem. Phys., 8, 50995111, doi:10.5194/acp-8-5099-2008, 2008.

Zhang, Q., Alfarra, M. R., Worsnop, D. R., Allan, J. D., Coe, H., Canagaratna, M. R., and Jimenez, J. L.: Deconvolution and quantification of hydrocarbon-like and oxygenated organic aerosols based on aerosol mass spectrometry, Environ. Sci. Technol., 39, 4938-4952, 2005.

Zhou, Y., Zhang, H., Parikh, H. M., Chen, E. H., Rattanavaraha, W., Rosen, E. P., Wang, W., and Kamens, R. M.: Secondary organic aerosol formation from xylenes and mixtures of toluene and xylenes in an atmospheric urban hydrocarbon mixture: Water and particle seed effects (II), Atmos. Environ., 45, 38823890, doi:10.1016/j.atmosenv.2010.12.048, 2011. 